\title{
Impairment of Goodwill: Level of Compliance and Quality of Disclosure during the Crisis An Analysis of Italian Listed Companies
}

\author{
Maria Federica Izzo ${ }^{1}$, Valerio Luciani ${ }^{2} \&$ Elisa Sartori ${ }^{1}$ \\ ${ }^{1}$ Department of Business and Management, LUISS Guido Carli University, Italy \\ ${ }^{2}$ Department of Economic, Political Sciences and Modern Languages, Libera Università Maria Ss. Assunta, Italy \\ Correspondence: Maria Federica Izzo, Department of Business and Management, LUISS Guido Carli University, \\ Rome, Via Salvini 2, 00197 Rome, Italy. Tel: 39-06-8522-5045. E-mail: fizzo@luiss.it
}

Received: August 5, 2013

doi:10.5539/ibr.v6n11p94
URL: http://dx.doi.org/ibr.v6n11p94
Online Published: October 28, 2013

\begin{abstract}
This paper investigates the level of disclosure on impairment test of goodwill in the Italian context. The research is based on the analysis of the consolidated financial statements 2007-2011 of companies listed on FTSE MIB of Milan Stock Exchange at 31st December 2012. The main objective of the research is to verify if financial crisis has impacted on the level of compliance with IAS 36 and Guidelines issued by Italian Authorities. In addition, it tests if there are any relations between the level of disclosure and factors such as market capitalization, the ratio Goodwill on Equity and Impairment loss/Goodwill. Our results show that the quality of disclosure is still incomplete, even if it is clear that there is a significant improvement in the period covered by the analysis. In addition, we observe that, at least in relation to our data, there is no relation between the quality of mandatory disclosure on goodwill and the mentioned factors.
\end{abstract}

Keywords: impairment, goodwill, disclosure, IAS 36, compliance, value in use, market capitalization

\section{Introduction}

In 2011 Italy has been the European country that has most impaired assets recognized in the financial statements of listed companies (mainly goodwill). The amount of impairment has been over35 billion euros, equal to six times the total amount impaired in the previous 4 years (2007-2010) and the estimates for 2012 seem to confirm the need for further impairment.

Goodwill is one of the most controversial company assets, and this controversial nature is not just related to its definition but also to its quantification and accounting treatment (Bloom, 2009).

The impairment test procedures represent one of the most critical aspect of IAS/IFRS implementation (IFRS Foundations, 2013a), both for the high complexity and subjectivity of the evaluation process required by IAS 36, Impairment of assets (International Accounting Standard Board (IASB), 2004a) and for the incidence of these intangible assets in companies' financial statements (in relation to total assets, equity and market capitalization).

The recent financial crisis has led, in many cases and with no differences among countries, to a severe correction of the estimated financial cash flows and performance expectation formulated before the crisis with a clear and unavoidable impact on financial statements. At the same time, the ratio between market capitalization and equity has dramatically dropped off and for a number of companies it is less than one (Organismo Italiano di Valutazione (OIV), 2012). That leads to an increase, at least hypothetically, in the probability that the Cash Generating Unit (CGU) carrying amount is less than its recoverable amount.

In this macro-economic scenario many researchers have argued that concrete doubts exist on impairment real capability to fairly represent the company results, to offer reliable information and to inform financial markets and investors (Guatri, 2009; Liberatore, Ridi \& Di Pietro, 2012). In June 2012, IASB Chairman Hans Hoogervost underlined the existence of a general delay, especially in this critical moment, in recognizing the impairment losses in companies' financial statements. In the light of the above, IASB is even considering, with concern to the IFRS 3 post-implementation, the possibility to re-adopt the goodwill amortization over its useful lifetime. 
Starting from these doubts and concerns, our paper focuses on goodwill impairment test disclosure, addressing two main research questions:

(a) is the disclosure provided by Italian listed companies compliant with the IAS 36 requirements?

(b) has this disclosure changed (both in terms of compliance and accuracy) before and after the financial crisis explosion?

Some recent literature contributions, analyzing only the mandatory disclosure, demonstrate that the disclosure quality among European companies on goodwill impairment test is very poor (European Securities and Markets Authority (ESMA), 2013; Devalle \& Rizzato, 2012; Hartwig 2012) and that in the Italian scenario, in contrast to the English one, a strong and robust positive relation between the impairment loss and the disclosure level exists, due to potential earnings management dysfunctions (Massoud \& Raiborn, 2003; Watts, 2003; D'Alauro, 2011).

Foremost, the relevance of this topic is confirmed by IASB that, through the Exposure Draft Recoverable Amount Disclosures for Non-Financial Assets (IASB, 2013), is trying to revise and adapt information rules about goodwill impairment test to the actual international situation.

Our research concerns the evaluation of the compliance level with the provisions of IAS 36 provisions (par. 134 about the CGU recoverable amount) and the quality of the disclosure provided in accordance with this standard, by reviewing the consolidated financial statements of a sample made up of 40 Italian companies, listed on the FTSE-MIB Italian Stock Exchange in the period 2007-2011.

In relation to our sample, the banks analyzed present a ratio Goodwill/Market capitalization equal, on average, to $63,61 \%$, while for industrial companies the ratio Goodwill/Invested Capital is, on average, $15 \%$ and higher than $30 \%$ for 1 company out of 5 .

The analysis is enriched by taking into account the requirements and best practices presented in other documents and guidelines provided by Italian Authorities: Bancad'Italia (central bank of the Republic of Italy); CONSOB (the supervisory authority regulating the Italian securities market) and ISVAP (now IVASS, Institution for the supervision of insurance). The required additional information regards, starting from 2009 financial statements, the discount rate components, the sensitivity analysis, the differences between the amounts of the key assumption in the current period and the same ones in the previous year and the reasons why, even if there are signs of impairment's value of an asset, the entity didn't register an impairment loss. The time horizon has been chosen in order to distinguish between a pre-crisis period (2007-2009) and a crisis-affected period (2010-2011).

Thus, the aim of this analysis is to verify if the crisis worsening and the external impairment indicators have led Italian companies to improve the quality of their financial disclosure both in the case of an impairment loss recognition and in the opposite case. Our starting idea, in fact, is that especially in the depicted contest, where an impairment's indicator is more probable than not, the decision not to impair goodwill should require even more clear and accurate disclosure that the one presented when entities register an impairment loss.

In order to test our hypothesis, a compliance matrix is built and a score is assigned to each company in order to verify the level of goodwill's disclosure compliance and its variation during the period covered by the analysis. The main analyzed aspects refer to the determination of growth rate, the disclosure about the discount rate, the sensitivity analysis, the dimension of impairment losses on goodwill, the percentage of goodwill to total assets, the equity/market capitalization ratio and the goodwill/equity ratio.

Our first results reveal a material level of non-compliance and quite a high level of variation both in the quality and precision of the information presented in relation to impairment assumptions and testing procedures. The major deficiencies concern the assumptions used in order to define the expected flows and the terminal value. The discount and growth rates are often presented but rarely commented on in a proper way and thoroughly defined (as explicitly requested by the Italian Authorities and the Italian Standard Setter). In particular, the paper deals with factors that may explain why some firms are not entirely compliant with IAS 36 . The analysis of this non-compliant information gave us the possibility to define best practices, discuss on policy recommendation and potential rules-improvement and, finally, to identify directions for future research. The paper offers some remarks to improve the quality of goodwill disclosure, also in order to submit useful findings to IASB in the process of accounting standard setting: IFRS Foundation, as confirmed in the new Due Process Handbook (IFRS Foundation, 2013b), has set out the new due process principles, where it is considered that the IASB, also through the ASAF's role, will use fieldwork to support the development of changes in IAS/IFRS.

In order to provide shareholders with relevant information, it seems particularly important to examine IAS 36 requirements that ask to disclose on goodwill impairment in an entity-specific manner and not in a generic and vague way. In this regard, if the level of uncertainty in an estimate is sufficiently large, transparency and 
accuracy of disclosure are essential to ensure that the faithful representation of the phenomenon is presented in financial reports (IASB, 2010).

The paper is structured as follows: in section "Regulatory framework" we analyze the requirements of IASB and recommendations of Italian Authorities in order to better introduce the section "Literature review" in which the theoretical framework is presented and the main assumptions of the work are introduced. In section "Methodology" the sample is explained and all the variables are presented. Finally, the section "Empirical results" shows the main results of the model.

The article concludes by considering the results and the limits of this study with further research/analisys in the "Conclusions" section.

\section{Disclosure of Goodwill: Regulatory Framework}

The current version of IAS 36 Impairment of Assets was issued in April 2004 within the project on business combination's reform (IASB, 2004b). The original text of IAS 36 has been amended by IFRS 3 revised in 2008 and endorsed by Regulation CE n. 495/2009. Further amendments have been made by Annual Improvements to IFRSs 2007 (endorsed by Regulation CE n. 70/2009) and 2009 (endorsed by Regulation CE n. 243/2010).

Substantial changes have impacted on accounting and disclosure's requirements on impairment test following the issue of IFRS 13 Fair Value Measurement, enacted in May 2011 and endorsed by Regulation n. 1255/2012 (IASB, 2011).

Impairment test describes the procedures that an entity applies to ensure that its assets are carried at no more than their recoverable amount, defined as the higher of an asset's fair value less costs to sell ("fair value less transaction cost" according the new terminology introduced by IFRS 13) and its value in use.

The impairment procedure usually starts when trigger events, both related to external and internal source, arise, but the existence of impairment indicator does not imply automatically the recognition of an impairment loss.

The assets under scope of IAS 36 are impaired only if evaluation's process confirms that the "fundamental" value of the asset (or group of assets) is lower than carrying value.

IAS/IFRSs require a detailed disclosure on the estimation made to ascertain the carrying value of goodwill and carrying value of intangible assets with indefinite useful life (from now on, only goodwill) recognized in the financial position (both individual and consolidated).

It is important to clarify that the disclosure's obligations are compulsory for the CGUs that have a significant allocated goodwill's portion on the total carrying value of goodwill. The CGU is the smallest identifiable group of assets that generates cash inflows that are largely independent of the cash inflows from other assets or groups of assets.

IAS adopters are required to disclose the carrying amount of goodwill (or of intangible assets with indefinite useful life) allocated to the CGU and the basis of value (value in use or fair value) elected to estimate the recoverable amount of CGU (IAS 36, par. 134, lett. c).

The information required by IAS 36 on impairment test is different according the adopted basis of value for CGU recoverable amount's estimation.

If recoverable amount is based on value in use, the entity has to describe each key assumption (IAS 36, par. 134, lett. d. i) which the unit's (group of units) recoverable amount is most sensitive and the approach adopted to assign a value to each key assumption.

It is also necessary to specify whether those values reflect past experience or, if appropriate, are consistent with external sources of information (IAS 36, par. 134, lett. d. ii).

For this reason, the current text, that is different from the Exposure Draft that was published before IAS 36 revised 2004, does not require:

- the values assigned to each key assumption;

- the change that each key assumption should register in order for the CGU's recoverable amount to be equal to its carrying amount. According to the current requirements, entities have to provide this information only if a reasonably possible change in a key assumption would cause the CGU's carrying amount to exceed its recoverable amount. Under this circumstance, the preparers have also to disclose the amount by which the CGU's recoverable amount exceeds its carrying amount (IAS 36, par. 134, lett. f) and the amount by which the value assigned to the key assumption must change, after incorporating any consequential effects of that change on the other variables used to measure recoverable amount, in order for the unit's (group of units') recoverable 
amount to be equal to its carrying amount. It can be deduced that this disclosure obligation is excluded implicitly if there is a goodwill impairment loss.

Taking into account the views of respondents to the public consultation of mentioned Draft, the Board has concluded that the requirement to disclose the values assigned to every single sensitive assumption went beyond the goals set in order to guarantee a satisfactory level of disclosure for the users. The users of financial statement, as far as we concern, are interested in the reliability of estimation process of impairment test.

In the details, this requirement should expose IAS adopters to the risk of litigation, especially if quantitative data reported in the Notes were not accurate.

The proposal for a legal action based on values assigned to each key assumption should lead to the management to engage independent experts to develop all key assumptions or to use super-conservative assumption, thereby resulting in improper asset write-downs.

At the same time, it is important to notice that above explained approach does not concern the discount rate of future cash flows and the growth rate of terminal value's cash flow. IAS 36 requires the amount assigned to these two key assumptions, irrespective the results of impairment test and the uncertainty of economic evaluations used to perform the test.

For this reason, if the preparer uses a growth rate to extrapolate cash flow projection higher than long- term average growth rate for the products, industries, or country in which the entity operates, this choice has to be justified (IAS 36, par. 134, lett. d.iv e d.v.).

Finally, as far as the value in use, the entities have to declare the period over which management has projected cash flows based on financial budgets/forecasts approved by management and, when a period greater than five years is used for a cash-generating unit (group of units) an explanation for the adoption of a longer period (IAS 36, par. 134, lett. d.iii).

If the recoverable amount of CGU is based on fair value less costs to sell, the level of disclosure depends on the approach that has been adopted.

If it is used the market approach through observable market prices, it is enough to give information on the methodology (IAS 36, par. 134, lett. e); in case of adoption of alternative criteria (i.e., the income approach) IAS 36 revised 2004 was limited to require the description of key assumption (par. 134, e.ii) and the approach used to assign an amount to these key assumptions (IAS 36, par. 134, lett.e.ii).

As a consequence, the level of disclosure under the adoption of income approach to estimate the fair value was lower than the one required for the value in use.

IASB has amended this incoherence through the issue of Improvements to IFRS 2007 (published on 2008) that has introduced, even for the evaluation of fair value through income approach, the requirement on the disclosure of the growth rate used to extrapolate cash flow projections and the discount rate applied to the cash flow projections (par.134, e.iii, iv e v).

This amendment, that represents an improvement as far as the financial reporting's transparency, is particularly significant because it has eliminated the doubt about the application of income approach for the estimation of fair value.

It is useful to remark that IAS 36 does not define analytical rules for the projection of future cash flows and discount rate for the fair value, in contrast to what is required for value in use.

As outlined earlier, IFRS 13, published in May 2011 and become effective 2013, amends significantly some disclosure's rules of IAS 36 .

These changes have a double goal: to extend the disclosure on recoverable amount of assets under impairment (particularly if the estimation is based on fair value) and to balance the disclosure required if fair value is adopted and the disclosure required if the value in use is adopted.

Focusing on the amendment on goodwill, current IAS 36 requires to disclose the recoverable amounts of CGUs for which the carrying amount of goodwill and intangible assets with indefinite useful life allocated is significant.

This new requirement obliges IAS adopters to disclose the final result of evaluation performed in application of impairment test in the notes.

A new requirement, in case CGU's recoverable amount is based on fair value, concerns the obligation to give information on the level of hierarchy of fair value and on contingent change of evaluation technique and the 
reason that justifies this accounting behavior.

As evidence of the importance of this subject for the IASB, in January 2013 IASB has published an Exposure Draft that proposes some amendments, just introduced by IFRS 13, on IAS 36 as far as the disclosure.

The Draft remarks that originally IASB intended to require the entities to disclose the recoverable amounts of impaired CGUs (or of CGU that have been object of reversal in the current period).

On the contrary, IAS 36 revised 2011 has extended this requirement to all CGUs for which the carrying amount of goodwill allocated to that unit is significant, nevertheless the recognition of an impairment loss.

The amendments to par. 130 and 134 of the Draft should allow to align the text of the Standard to the real purposes declared by IASB. Without addressing the issue, it seems quite surprising that IASB recognizes to have enacted requirements that are contradictory with the expected goals.

In addition, the Draft includes an amendment that has been already inserted in the Draft to Improvements to IAS/IFRS 2010-2012. This amendment requires to disclose the discount rate that was used in a present value technique in order to determine the recoverable amount of impaired assets, regardless of whether that recoverable amount was based on fair value or on value in use.

At a national level, OIC (Organismo Italiano di Contabilità, the Italian Accounting Standard Setter) has enacted the Application n. 2 "Impairment and Goodwill" in December 2009 for not financial entities. This document addresses the practical application of IAS 36 as far as the measurement of goodwill, providing the users with useful formats in terms of graphs used to insert the numerous information required by IAS 36 (OIC, 2009).

In substantial terms, OIC focuses on the obligation to provide with adequate information on the ways used to determine the terminal value (perpetuity annuity or temporary annuity) and on the related discount rate that, so far as known, could be different from the discount rate used for the cash flows for the period covered by the most recent forecast.

The economic and financial crisis of 2008 has induced the Regulatory Authorities (Banca d'Italia, ISVAP and CONSOB) to enact some recommendations to request the application of requirement on impairment test for Board of directors and for Board of statutory auditors of Italian listed companies.

The communication of 6 February 2009 has this purpose: the Authorities have called attention the Boards of Italian under surveillance to disclose information adequate according the requirements of IAS 36 on impairment test (Banca d'Italia, ISVAP \& CONSOB, 2009).

Document n. 4 published in 2010 face the issue in more detail, remarking the need to provide, starting from period 2009, with more exhaustive information as far as some critical phases of impairment test ex-IAS 36 (Banca d'Italia, ISVAP and CONSOB, 2010).

Particularly, Regulatory Authorities believe that impairment's process should be approved "separately" before the approval of financial statement.

As far as the disclosure, The Authorities, in addition to the requirements of IAS 36, oblige the entities to disclose the components of discount rate and to specify whether it is used a rate before or after taxes and the amount of the previous period.

It is also required to focus the preparers on the existence of external impairment indicators and to disclose adequately the contingent not alignment between the market's evidences and the impairment test's result. In example goodwill is not impaired although market capitalization is lower than book value.

The authorities seem to suggest the entities to report the results of sensitivity analysis even if there is absence of conditions required by IAS 36, par. 134, lett.f. (the first condition regards the reasonably possible change in a key assumption on which management has based its determination of CGU's recoverable amount and the second condition is that this reasonable change causes the recognition of an impairment loss).

The recommendations of Regulatory Authorities on goodwill's disclosure have been recalled on Application of OIC: Application 2.1. Impairment and goodwill for banking sector (OIC, 2011a) and Application 2.2. Impairment and goodwill for insurance sector (OIC, 2011b).

Italian Standard Setter believes that the information about the components of discount rate has to be provided only at a descriptive level. This interpretation is not reported in the Document n. 4 of Regulatory Authorities.

OIC Applications give evidence of obligation to perform sensitivity analysis on the change of future cash flows, growth rate and discount rate. Therefore, a sensitivity analysis conducted only on a single evaluation's driver (i.e., discount rate) is not considered exhaustive and is not compliant with IAS 36 (ESMA, 2013). 


\section{Literature Review}

There has been a considerable number of recent studies regarding the accuracy and level of compliance of financial statements disclosure. The importance of providing reliable and compliant disclosure there have been particularly evident for companies applying IAS/IFRS, considering the volatility of performance that is likely to result from the increased use of fair value (Verriest \& Gaeremynck, 2009; Petersen \& Plenborg, 2010)

The research on this topic can be divided in two parts: the first one faces the general quality of the disclosure; the second one is focused and limited to the disclosure on specific items.

Concerning the first aspect, the literature contributions have focused particularly on the association between the level of disclosure and the cost of equity (Botosan, 1997; Botosan, 2006; Botosan \& Plumlee, 2012; Armitage \& Marston, 2008; Barth, Landsman \& Lang, 2008).

Other researchers, focusing on the effect of IAS/IFRS adoption process, have demonstrated that the quality of financial statements of companies adopting IAS has increased significantly for companies of the countries analyzed (Austria, Germany and Switzerland), leading to higher liquidity in the capital markets and lower cost of capital to the reporting entities (Daske \& Gebhardt, 2006).

Disclosure is a key factor in investing process: Douglas and Verrecchia (1991) have shown that revealing public information to reduce information asymmetry can reduce a firm's cost of capital by attracting increased demand from large investors due to increased liquidity of its securities; Daske and Hail have demonstrated that "serious" IFRS adopters have experienced an increase in liquidity and a decline in cost of capital (Daske, Hail, Leuz \& Verdi, 2013).

The issue on impairment test of goodwill is related to the topic regarding the accounting of goodwill, composed of two indistinguishable parts: internally generated goodwill, that can't be accounted for, and purchased goodwill that is recognized in the financial statement. Bloom (2009) stated that it can confidently be expected that, as anomalies and practical difficulties manifest themselves in practice, the current impairment regime will, in its turn, be abandoned. The last developments on this issue seem to demonstrate the reasonability of these considerations.

About specific research on the level of disclosure, it is important to notice that, as analyzed in the paragraph on Regulatory framework, some authors suggest that the goodwill's Impairment Test will satisfy the need for analysts for better information about intangible assets (Donnelly \& Keys, 2002). Some research papers have also demonstrated that Impairment regime reflects the underlying economic attributes of goodwill than do amortization charges, finding the association between firms' goodwill charges against income and the firm's investment opportunities (Chalmers, Godfrey \& Webster, 2011). IAS 36 is a complicated standard that requires valuation techniques' knowledge. IAS 36 impairment disclosure should provide users of financial statements with better information as goodwill is not amortized (Colquitt \& Wilson, 2002).

At international level, some of the evidence relating to the level of disclosure regarding teh impairment test for goodwill comes from analysis on listed Australian market (Carlin \& Finch, 2010). The authors have found that the impairment test information is not so clear and "compliant", also because of the recent vicissitudes in financial markets. They have found a material level of "no-compliance" and a material degree of variation in the quality of disclosure pertaining the impairment test procedures.

Similar results are contained in the paper of Hartwig (2012) that has found that the compliance level of goodwill's disclosure for Swedish and Dutch listed companies is low, registering an increase over the time covered by the analysis.

Among the most recent research contributions on the topic, the analysis performed by Devalle and Rizzato (2012) on the quality of mandatory disclosure of goodwill for European listed companies for period 2010 statement. The authors have verified whether the mandatory disclosure is shown in the notes of consolidated financial statements of Italian, French, German and Spanish companies. The results show that the disclosure index is very low and there are significant differences among the stock markets analyzed by the Authors.

Petersen and Plenborg (2010) made an assessment of disclosure quality and compliance levels conducted on Danish listed firms pointing out that a common practice on impairment test of goodwill has not yet been established. The authors have examined how firms implement impairment test of goodwill focusing on the definition of a cash generating unit and how firms measure the recoverable amount of a CGU. They found that some firms do not define a CGU in compliance with IAS 36 and they also have registered some inconsistencies in the way that firm estimate the recoverable amount (the discrepancies regard especially before-tax discount rate, adjusting for risk, and estimating the cash flow in the terminal period). 
An interesting application of a model for measuring the level of disclosure about intangibles developed by University of Ferrara is exposed in the contribution of Bergamini and Zambon (2001). They have appreciated the level of information on intangibles disclosed by Italian, French, German and UK companies in 2001 annual reports. This analysis, that has been developed on financial statements prepared before the application of IAS/IFRS, has demonstrated that traditional financial statements are not able to provide any interesting information on the intangible assets that are key to the company. This contribution has also proved that Continental European companies supply much more information on intangible assets than UK companies.

Some interesting research on this topic has been led by Camodeca and Almici (2012). They have demonstrated that in the European banking sector the level of disclosure regarding the components of Discounted Cash Flow Model used to estimate the recoverable amount increased during the period 2006-2011, and especially after the financial crisis, even if the level of compliance disclosure is lower for some specific topic such as discount rate, growth-rate and terminal value.

In relation to Italian listed companies, Liberatore, Ridi and Di Pietro (2012) have examined the value relevance and reliability perceived by the markets for goodwill and intangible assets recognized in the financial statement for the period 2002-2008, concluding that information relating these intangibles is value relevant in terms of market value.

Teodori and Veneziani (2010) have conducted an analysis on the three main Italian Stock Market indexes in terms of disclosure of intangible assets as required by IAS 36 with the analysis of consolidated financial statements for 2005 and 2006 periods. The level of disclosure in compliance with IAS 36 is summarized through the construction of a "disclosure index". It has emerged that there is not only little voluntary information but at times there is also little mandatory information concerning the most delicate aspects introduced by the IAS 36 .

Specifically, some research contribution focuses on some specific information of impairment test regarding the discounted rate for the estimation of value in use for goodwill (Liberatore \& Mazzi, 2011). The mentioned analysis compares a sample of Italian companies and a sample of North European country in order to evaluate whether the mandatory disclosure quality is related to the significance that intangible assets have in North European countries. The results demonstrate that the discount rate disclosure level used in estimating goodwill increases following a goodwill write-off.

Another relevant study that contributes to the debate on the appropriateness of disclosure regarding the Impairment Test of goodwill is the one conducted on Italian companies listed on Milan Italian stock exchange by Biancone (2012). The author has analyzed the information offered in terms of disclosure of impairment test of goodwill by consolidated financial statements of companies listed on the Italian Stock Exchange for the periods 2007-2009. The research found that most Italian companies offered incomplete and not compliant disclosure, finding that there is no connection between the recorded amount of goodwill or its impairment and the amount of information.

The importance of a full and compliant disclosure on Impairment test of goodwill in the financial statements is particularly significant: the investors need reliable and material information to help them determine whether they should buy, hold or sell the company's equity instruments. The investors penalize much more the "opacity" of disclosure than the impairment loss: a better quality of disclosure on Impairment Test will offer an important contribution to the answer to financial crisis. Impairment test is not an "accounting act" but an instrument of control and communication to financial markets (Guatri \& Bini, 2009).

This paper is focalized on the disclosure of impairment test of goodwill that requires numerous assumptions to be made in estimating recoverable amount. Considerable ambiguity and subjectivity are inherent in this IFRS requirement (Wines, Dagwell \& Windsor, 2007).

This paper contributes to existing literature giving interesting results on goodwill impairment disclosure of Italian listed companies for periods 2007-2011 focusing on the analysis of compliance according to IAS 36 through a differentiation for specific topic.

We highlight the critical aspects of disclosure that are particularly sensitive to the discretion of management and to the uncertainty of Financial Crisis. The analysis of current practice of listed Italian companies is a good starting point to evaluate the major difficulties companies face to carry out goodwill's Impairment Test and to reflect on some critical aspects of IAS 36 .

This analysis could be of interest to companies, auditors, financial advisors, users of financial statements and standard setters in order to offer some remarks to improve the quality of goodwill's disclosure and to discuss on policy's recommendation and potential rules' improvements. 


\section{Hypotheses}

This research aims to answer to the following questions about level of disclosure on goodwill's Impairment for a sample of Italian listed companies:

a) are Italian listed companies compliant with requirements of IAS 36 par. 134?

b) can we have some evidences of a disclosure's improvement during the period 2007-2011?

c) are Italian listed companies compliant with recommendations of Italian public Authorities and of Italian Standard Setter on this topic?

d) are there any relations between level of disclosure and some factors, such as market capitalization and ratios like G/E (goodwill on equity), I/G (impairment loss/goodwill)?

According to previous contributions (Carlin \& Finch, 2010; Hartwig, 2012; Devalle \& Rizzato, 2012; Petersen \& Plenborg, 2010; Teodori \& Veneziani, 2010; Biancone, 2012) expect that, in the Italian scenario, there is a lack of compliance both with the requirements of IAS 36 and with Italian public Authorities and Italian Standard Setter. The critical aspects could be related to the quality and precision of the information presented in relation to impairment assumptions and testing procedures. In relation to question b), our starting idea is that especially in the depicted contest, where an impairment indicator is more probable than not, the decision not to impair goodwill should require even more clear information and accurate disclosure that the one presented when entities recognizing an impairment loss. For that reason, we expect to find an increase in the disclosure score of the analyzed companies from 2007 to 2011.

As far as the question d) is concerned, the investors of financial markets penalize much more opacity of disclosure than the impairment loss (Guatri \& Bini, 2010); so we can assume that listed companies are more sensitive to disclosure problems, perhaps due to reputational problems. In addition, we expect that when the G/E ratio is high, companies are more interested in offering a detailed information on goodwill and when the $\mathrm{I} / \mathrm{G}$ ratio is relevant, companies are expected to disclosure more and more in detail, as the market is particularly sensitive to these kind of loss. Hence, we expect a positive relation between the level of disclosure and market capitalization, G/E and I/G.

In order to test our hypothesis, we have built disclosure grids and we have assigned a score to the panel companies in order to verify the level of goodwill's disclosure compliance in the period 2007-2011 and its variation during the period covered by the analysis.

The main aspects we have considered refer to the information on basis of value, determination of growth rate, disclosure about discount rate and cash flow and sensitivity analysis.

\section{Methodology}

This research is structured by 5 phases:

- data collection and identification of companies included in the sample;

- construction of assessment grids on goodwill disclosure provided in the financial statement;

- "disclosure index" construction;

- calculation of disclosure index for each company included in the sample;

- evaluation of results through:

a) analysis in order to determine the relevance of goodwill on total assets and on total equity and in order to investigate the basis of value used by companies to evaluate recoverable amount of CGU (this is particularly important because the disclosure rules depend on adopted basis of value).

b) the determination of descriptive statistics' indicators (mode, mean and median);

c) the analysis of correlation test between disclosure index and some relevant parameters mentioned in our research hypotheses (see par. 6).

\subsection{First Phase-Data's Collection and Identification of Companies Included in the Sample}

In the first phase, we have collected the consolidated financial statements for a sample of Italian companies that are listed on FTSE MIB of Milan Stock Exchange at 31st December 2012 and it covers a period of 5 years, from 2007 until 2011.

The FTSE MIB is the primary benchmark Index for the Italian equity markets. Capturing approximately $80 \%$ of the domestic market capitalization, the Index is derived from the universe of stocks trading on the Borsa Italiana 
main equity market.

The sample is heterogeneous and includes companies belonging to different industries, as presented in Table 1 .

Table 1. Companies analyzed

\begin{tabular}{|c|c|}
\hline Company & Industry \\
\hline Banca Monte Paschi Siena & Banking \\
\hline Banca Popolare Emilia Romagna & Banking \\
\hline BancaPopolare Milano & Banking \\
\hline BancoPopolare & Banking \\
\hline IntesaSanpaolo & Banking \\
\hline Mediobanca & Banking \\
\hline Mediolanum & Banking \\
\hline UbiBanca & Banking \\
\hline Unicredit & Banking \\
\hline Azimut Holding & Financial \\
\hline Exor & Financial \\
\hline Generali & Insurance \\
\hline $\mathrm{A} 2 \mathrm{a}$ & Manufacturing and Service \\
\hline Ansaldo Sts & Manufacturing and Service \\
\hline Atlantia & Manufacturing and Service \\
\hline Autogrill & Manufacturing and Service \\
\hline BuzziUnicem & Manufacturing and Service \\
\hline Campari & Manufacturing and Service \\
\hline Diasorin & Manufacturing and Service \\
\hline Enel & Manufacturing and Service \\
\hline Enel Green Power & Manufacturing and Service \\
\hline Eni & Manufacturing and Service \\
\hline Fiat & Manufacturing and Service \\
\hline Fiat Industrial & Manufacturing and Service \\
\hline Finmeccanica & Manufacturing and Service \\
\hline Impregilo & Manufacturing and Service \\
\hline Lottomatica & Manufacturing and Service \\
\hline Luxottica & Manufacturing and Service \\
\hline Mediaset & Manufacturing and Service \\
\hline Parmalat & Manufacturing and Service \\
\hline Pirelli \& C & Manufacturing and Service \\
\hline Prysmian & Manufacturing and Service \\
\hline Salvatore Ferragamo & Manufacturing and Service \\
\hline Saipem & Manufacturing and Service \\
\hline Snam & Manufacturing and Service \\
\hline Stmicroelectronics & Manufacturing and Service \\
\hline
\end{tabular}




\begin{tabular}{ll}
\hline Telecom Italia & Manufacturing and Service \\
Tenaris & Manufacturing and Service \\
Terna-Rete ElettricaNazionale & Manufacturing and Service \\
Tod's & Manufacturing and Service
\end{tabular}

In Table 2 the number of observations are indicated in the sample for each year covered by the analysis. The number of observations per year is equal to the difference between the total companies in the Index FTSE MIB at 31st December 2012 and the companies excluded from the observation.

Table 2. Observations

\begin{tabular}{lccrrr}
\hline & $\mathbf{2 0 0 7}$ & $\mathbf{2 0 0 8}$ & $\mathbf{2 0 0 9}$ & $\mathbf{2 0 1 0}$ & $\mathbf{2 0 1 1}$ \\
\hline Companies in the Index at $31^{\text {st }}$ December 2012 (a) & 40 & 40 & 40 & 40 & 40 \\
Companies excluded (b) & -8 & -5 & -4 & -3 & -3 \\
Number of observation (a-b) & $\mathbf{3 2}$ & $\mathbf{3 5}$ & $\mathbf{3 6}$ & $\mathbf{3 7}$ & $\mathbf{3 7}$ \\
\hline
\end{tabular}

Companies have been excluded for two reasons: lack of financial statement IAS/IFRS compliant for one or more period (companies that have been constituted after 2010 or listed after 2010) and no goodwill or irrelevant goodwill recognized in financial statement (Goodwill on Total Asset less than 0,04\%).

In this way we have obtained the smallest number of missing data and a reliable sample dataset.

Data extracted for the analysis have been extrapolated from:

- consolidated financial statements for the period covered by analysis: 2007-2011;

- Data stream and Osiris database's resources for market data.

\subsection{Second Phase-Construction of Assessment Grid}

The most important step of our research has been the construction of assessment grids on goodwill disclosure provided in the financial statement.

In relation to goodwill disclosure, we have built two grids:

(a) "mandatory disclosure grid" according to IAS 36 requirements;

(b) "recommended disclosure grid" examining the guidelines provided by Italian Standard Setters and Italian public Authorities.

Every grid is composed of two columns: the first one concerns the specific requirement that company has to apply in the notes and the second one contains the pertaining score assigned to each company.

\section{Mandatory disclosure grid}

This grid has been constructed on the basis of requirements contained in IAS 36, paragraph 134.

Particularly, the disclosure's requirements have been grouped in the following four areas, in order to simplify the evidence of the analysis:

- Basis of value;

- Value in use, divided into:

a) cash flow projection;

b) terminal value;

c) discount rate;

d) growth rate;

e) coherence of key assumptions;

- Fair Value;

- Sensitivity Analysis. 
The requirements included in each cluster have not extracted sic et simpliciter from IAS 36 but it's also a result of an interpretation based on the best theories and best practices on the subject, such as recommendation of Accounting Standard Setter.

Table 3. Mandatory disclosure requirements

Mandatory Grid

\section{Basis of value}

Has the entity disclosed the basis on which the CGU's recoverable amount has 0 point $=$ information not included determined (fair value or value in use)?

1 point $=$ information complete

Value in use (the information below are required only if company has applied this basis of value. If not the score is for each requirement $\mathrm{N} / \mathrm{A}$, not applicable)

Value in use-Disclosure on future cash flow for the period covered by the most recent budget/forecast

Has the entity disclosed each key assumption of macro-economic source on which management has based its cash flows projections for the period covered by the most recent budgets/forecasts (IAS 36, par. 134, letter d) i).

Has the entity disclosed each key assumptions of internal source on which management has based its cash flows projections for the period covered by the most recent budget/forecast? (IAS 36, par. 134, let. d) i).

Has the entity described the management's approach to determining the value(s) assigned to each key assumption on which management has based its cash flows projections for the period covered by the most recent budget/forecast? (IAS 36, par. 134 , lett. d) ii)

Has the entity disclosed the period covered by the most recent budget/forecast?

Has the entity disclosed the reasons that justify the adoption of a period covered by the most recent budget/forecast exceeding five years? (only if this option is exercised)

Value in use-Terminal value

Has the entity disclosed the approach applied to assign value(s) to each key assumption concerning future cash flows for the period over which management has projected cash flows based on financial budget/forecast?

Has the entity disclosed the approach to assign value(s) to each key assumption concerning discount rate used for the estimation of terminal value? (IAS 36, par. 134, let. d) ii)
0 point $=$ information not included

0,5 point $=$ information not complete (only one key assumptions is disclosed)

1 point $=$ information complete (more than one key assumption is disclosed)

0 point $=$ information not included

0,5 point $=$ information not complete (only one key assumptions is disclosed)

1 point $=$ information complete (more than one key assumption is disclosed)

0 point $=$ information not included

0,5 point $=$ information not complete (not for all key assumptions)

1 point $=$ information complete

0 point $=$ information not included

1 point $=$ information complete

$\mathrm{N} / \mathrm{A}=$ the period is less than five years

0 point $=$ information not included

1 point $=$ information complete

0 point $=$ information not included

1 point $=$ information complete (it is disclosed the approach to determine the terminal cash flow)

0 point $=$ information not included

1 point $=$ information complete (it is disclosed the approach to determine the discount rate applied to terminal cash flow or it is specified that this rate is the same of the one applied for the budget cash flows)

Value in use-Discount rate for the period covered by the most recent budgets/forecasts

Has the entity disclosed the approach adopted to assign value(s) of each key 0 point $=$ information not included 
assumptions concerning the discount rate? (IAS 36, par. 134, lett. d) ii)

Has the entity disclosed discount rate applied for the projections of cash flows?
0,5 point $=$ vague and general information (i.e. the entity only declares to have applied the CAPM)

1 point $=$ information complete

0 point $=$ information not included

1 point $=$ information complete

0 point $=$ information not included

1 point $=$ information complete

0 point $=$ information not included

1 point $=$ information complete

average growth rate for the products, industries, or country or countries in which the entity operates?

Has the entity explained the decision to adopt a growth rate exceeding the long-term average growth rate for the products, industries, or country or countries in which the entity operates? (only if this option is exercised)
$\mathrm{N} / \mathrm{A}=$ the growth rate does not exceed the growth rate for the industry, etc.

0 point $=$ the growth rate exceeds the one for the industry, etc. and the information is not included or it is not included the information on the previous requirement

1 point $=$ information complete

Value in use-Coherence of key assumptions

Has the entity disclosed if values assigned to each key assumption reflect past N/A = if company is fully or partially compliant experience? (IAS 36, par. 134, let. d) ii) with next requirement

0 point $=$ information not included

$0,5=$ information not complete

1 point $=$ information complete

Has the entity disclosed if values assigned to each key assumption differ from past N/A = if company is fully or partially compliant experience or external source of information? (IAS 36, par. 134, let. d) ii) with previous requirement

0 point $=$ information not included

0,5 point $=$ information not complete

1 point $=$ information complete

Fair Value (the information is required only if company has applied this basis of value. If not the score is for each requirement N/A, not applicable)

Has the entity described the methodology used to determine fair value less costs to 0 point = information not included sell?

1 point $=$ information complete

$\mathrm{N} / \mathrm{A}=$ if fair value is determined through market approach

0 point $=$ information not included

Has the entity described each key assumption on which management has based its determination of fair value less costs to sell?

0,5 point $=$ information not complete (only one key assumptions is disclosed)

1 point $=$ information complete (more than one key assumption is disclosed)

Has the entity described management's approach to determining the value (values) N/A = if fair value is determined through market assigned to each key assumption? approach

0 point $=$ information not included

0,5 point $=$ vague and general information

1 point $=$ information complete 
\begin{tabular}{ll}
\hline $\begin{array}{l}\text { Has the entity disclosed if values of each key assumption reflect past experience or, } \\
\text { if appropriate, are consistent with external sources of information? } \\
\text { approach }\end{array}$ & $\begin{array}{l}0 \text { point }=\text { information not included } \\
0,5 \text { point }=\text { information not complete } \\
1 \text { point }=\text { information complete }\end{array}$
\end{tabular}

Sensitivity analysis (only if a reasonably possible change in a key assumption on which management has based its determination of CGU's recoverable amount would cause the CGU's carrying amount to exceed its recoverable amount)

Has the entity disclosed the amount by which the CGU's recoverable amount N/A= if entity has impaired goodwill exceeds its carrying amount?

0 point $=$ information not included

1 point $=$ information complete

Has the entity disclosed the value assigned to the key assumption?

0 point $=$ information not included

0,5 point $=$ information not complete (only one key assumptions is disclosed)

1 point $=$ information complete (more than one key assumption is disclosed)

Has the entity disclosed the amount by which the value assigned to the key

0 point $=$ information not included

assumption must change, after incorporating any consequential effects of the change on the other variables used to measure recoverable amount, in order for the CGU's recoverable amount to be equal to its carrying amount?

0,5 point $=$ information not complete (only one key assumptions is disclosed)

1 point $=$ information complete (more than one key assumption is disclosed)

\section{Recommended disclosure grid:}

It is important to clarify that both OIC's Guidelines "Impairment and Goodwill" and Communications issued by Banca d'Italia, Consob and ISVAP concerning IAS/IFRS do not have the objective to introduce new accounting requirements but to facilitate the correct application of IAS/IFRS requirements.

However, as regards the disclosure on goodwill impairment test, the above-mentioned documents require the preparers to disclose some specific information not expressly required by IAS 36. In particular:

- the Application OIC n. 2 suggests to give information on the amount of goodwill allocated to CGU also for the previous period and the inclusion of chart on relations between CGU and operating segments in case CGU and operating segments do not coincide;

- the Communication enacted by Banca d'Italia, Consob and ISVAP in March 2010 requires the companies to:

(a) give information on identification of CGU compliant with the operating characteristics and with the strategic vision of the company;

(b) disclose the components of discount rate;

(c) clarify if the discount rate is after or before taxes;

(d) specify if the discount rate coincides with the one of the previous year;

(e) provide with complete information if companies do not impair carrying value of assets, even though there is a presence of external indicators of Impairment.

- the Applications OIC n. 2.1 and 2.2.- in addition to confirm the recommendation of disclosure required by above mentioned Authorities - require to banks and insurance companies to:

(a) specify the carrying amount of CGU;

(b) disclose the approach that has been applied to draw up budget;

(c) perform sensitivity analysis considering the hypotheses on flows, discount rate and growth rate;

(d) perform "variability" analysis in order to point out the impact on CGU's recoverable amount in case there is a simultaneous change of key assumption's values.

The requirements of these Guidelines have been effective starting from financial statements 2010. 
As this paper focalizes its attention on the disclosure concerning the evaluations of goodwill for Impairment test, the analysis on the level of compliance with Guidelines of OIC and Recommendations of Authorities has taken into consideration only the aspects concerning this topic.

The grids we have prepared to evaluate the level of compliance with the suggestion of Italian Standard Setter and Authorities are the following:

Table 4. Recommended disclosure requirements

\begin{tabular}{|c|c|}
\hline \multicolumn{2}{|l|}{ Recommended Grid } \\
\hline \multicolumn{2}{|l|}{ Discount rated is closure } \\
\hline Is it disclosed Risk free-rate? & 0point=information not included \\
\hline & 1point=complete \\
\hline & information(quantitative or descriptive) \\
\hline \multirow[t]{2}{*}{ Beta } & 0point=information not included \\
\hline & 1point=complete information \\
\hline \multirow[t]{2}{*}{ Risk premium } & 0point=information not included \\
\hline & 1point $=$ complete information \\
\hline \multirow[t]{3}{*}{ Cost of debt } & $\mathrm{N} / \mathrm{A}=$ entity uses equity's approach \\
\hline & Opoint=information not included \\
\hline & 1point $=$ complete information \\
\hline \multirow[t]{4}{*}{ Proportion of equity and debt on funding mix-if entity apply unlevered cash flow } & $\mathrm{N} / \mathrm{A}=$ entity uses equity's approach \\
\hline & Opoint=information not included \\
\hline & 1point=complete information \\
\hline & Opoint=information not included \\
\hline \multicolumn{2}{|l|}{ Has the entity specified if the discount rate corresponds to the one used in the previous period? } \\
\hline \multirow[t]{2}{*}{ Has the entity clarified if the discount rate is after or before taxes? } & Opoint=information not included \\
\hline & 1point $=$ complete information \\
\hline
\end{tabular}

Disclosure on external indicators of Impairment

Has entity disclosed on presumed indicators of external sources of information in a complete way? 0point=information not included Only if entity has not impaired goodwill

0,5 point=information not complete 1point $=$ complete information

$\mathrm{N} / \mathrm{A}=$ entity has impaired goodwill

Additional Recommended Grid for banks and insurance companies

\begin{tabular}{|c|c|}
\hline Requirement & Score \\
\hline $\begin{array}{l}\text { Has entity disclosed the approach that has been applied for the budget/forecast? (budget that has been } \\
\text { approved and publicized to the market; budget that has been approved and publicized to the market but } \\
\text { not more up-to-date) }\end{array}$ & $\begin{array}{l}\text { 0point=information not included } \\
1 \text { point }=\text { complete information }\end{array}$ \\
\hline \multirow[t]{2}{*}{$\begin{array}{l}\text { Has sensitivity analysis been conducted on the basis of following factors: future cash flow, growth rate, } \\
\text { discount rate? }\end{array}$} & $\begin{array}{l}\text { Opoint=information not included } \\
0,5=\text { informationnotcomplete(notmo } \\
\text { rethantwoassumptionsaredisclosed) }\end{array}$ \\
\hline & 1 point $=$ complete information \\
\hline \multirow[t]{2}{*}{ Has the entity carried out also a variability analysis? } & 0point=information not included \\
\hline & 1 point $=$ complete information \\
\hline
\end{tabular}




\subsection{Third and Fourth Phases - "Disclosure Index" Construction and Calculation}

We have calculated disclosure index for every period covered by the analysis for each company included in the sample and examined the disclosure in the notes of financial statement in order to evaluate the quality of disclosure for the requirements included both in the mandatory grid and in recommended grid. The total score is the sum of the assigned scores for each requirements; this is an absolute value, expressive of the company's disclosure level on goodwill's impairment test.

At the end we have calculated the annual disclosure index as the ratio between the total score and the total potential score, that represents the achievable score in case of full compliance.

This approach has been adopted both for mandatory disclosure and for recommended disclosure (in case of banks or insurance companies we have also scored the level of disclosure according to further guidelines, suggested by Italian Standard setter for those companies).

\section{Empirical Results}

\subsection{Preliminary Analysis}

In 2009 about $22 \%$ of companies in the sample has accounted an impairment loss of goodwill; this percentage has increased up to $35 \%$ in 2010 and in the last period analyzed (period 2011) the companies impairing goodwill were about $60 \%$.

It is also interesting to notice that in 2008 that has been the first year of financial crisis, about $43 \%$ of companies has impaired goodwill in comparison to almost $20 \%$ of companies in the previous year (see Table 5).

However (see Table 6), the amount of goodwill's write-down recognized in the period 2007-2010 is not comparable to values registered in the income statements of 2011 both in absolute level and in relative value (i.e., impairment rate, as ratio between impairment loss of goodwill and carrying value of goodwill: $1,73 \%$ in 2008 while almost $23 \%$ in 2011)

Inter alia, in general terms, mean incidence of goodwill on equity and mean incidence of goodwill on total assets remain stable in the course of time (see Table 7).

Table 5. Impairing entities

\begin{tabular}{lrrrrr}
\hline & $\mathbf{2 0 1 1}$ & $\mathbf{2 0 1 0}$ & $\mathbf{2 0 0 9}$ & $\mathbf{2 0 0 8}$ & $\mathbf{2 0 0 7}$ \\
\hline N $^{\circ}$ Impairing entities & 22 & 13 & 8 & 15 & 6 \\
N $^{\circ}$ Entities with goodwill & 37 & 37 & 36 & 35 & 32 \\
\% Impairing entities on total entities & $\mathbf{5 9 \%}$ & $\mathbf{3 5 \%}$ & $\mathbf{2 2 \%}$ & $\mathbf{4 3 \%}$ & $\mathbf{1 9 \%}$ \\
\hline
\end{tabular}

Table 6. Impairment rate

\begin{tabular}{|c|c|c|c|c|c|c|}
\hline Table 6. Impairment rate & \multicolumn{6}{|c|}{ Euro/million } \\
\hline & 2011 & 2010 & 2009 & 2008 & 2007 & 2006 \\
\hline Total Goodwill & 147.447 & 161.824 & 159.608 & 155.811 & 149.807 & 93.441 \\
\hline Total Impairment & 37.257 & 966 & 106 & 2.592 & 210 & \\
\hline Impairment rate* & $23 \%$ & $0.6 \%$ & $0.1 \%$ & $1.7 \%$ & $0.2 \%$ & \\
\hline
\end{tabular}

*Impairment rate (I/G) = Impairment period X/Goodwill 31.12.X-1

Table 7. Impact of goodwill on equity and on total asset

\begin{tabular}{lccccc}
\hline & $\mathbf{2 0 1 1}$ & $\mathbf{2 0 1 0}$ & $\mathbf{2 0 0 9}$ & $\mathbf{2 0 0 8}$ & $\mathbf{2 0 0 7}$ \\
\hline Goodwill/Equity & $50 \%$ & $44 \%$ & $47 \%$ & $57 \%$ & $52 \%$ \\
Goodwill/Total Asset & $12 \%$ & $12 \%$ & $12 \%$ & 0.13 & $14 \%$ \\
\hline
\end{tabular}

The above evidence - in particular the significant increase of impairment rate in 2011-seems to confirm the worries that have been revealed by IASB and recently by ESMA. The Board and European Securities and Markets Authority believe that the recognition of impairment loss in income statement often came too late during the financial crisis. 
It is important to clarify that this paper has not evaluated the accuracy and correctness of impairment procedures applied by the companies in the sample. In other words, the fact that a company has not impaired can't be considered a priori an IFRS not compliant behavior.

We have already pointed out that the content of disclosure on goodwill depends on the basis of value that has been used to evaluate the recoverable amount of CGU. Therefore, to understand the results of this research, it seems useful to describe the choice that has been made for the companies in the sample.

Value in use is the basis of value that has been chosen by almost all the companies in the period covered by the analysis; fair value is a basis of value that has been used just as a control method or, in some cases, fair value is used for minor CGU for which management has not the availability of data that are necessary to draw up budget or forecast.

Table 8 indicates, for any period, the number of companies as main criterion, for one or more CGU, the fair value as basis of value (also together with value in use).

Table 8. Impairment test based on fair value

\begin{tabular}{lccccc}
\hline & $\mathbf{2 0 1 1}$ & $\mathbf{2 0 1 0}$ & $\mathbf{2 0 0 9}$ & $\mathbf{2 0 0 7}$ \\
\hline Fair value & 0 & 1 & 3 & 2 \\
\hline
\end{tabular}

From our analysis, it is possible to notice that fair value is estimated through the market approach.

Therefore, at the moment, the income approach is not applied for the estimation of fair value. At this regard, if recoverable amount is based on fair value (less costs to sell) using observable market prices, IAS 36 requires the preparers to disclose the methodology that has been used (i.e., multiples from comparable firms or multiples from comparable transactions).

\subsection{IAS/IFRS Disclosure-Comprehensive Evaluation}

For all the companies in the sample, the compliance level is increasing from 2007 on. This improvement is evident from the results in Table 9.

In 2007 , no companies reached a compliance level higher than $80 \%$ and at the same time 16 companies out of 32 reached a level lower than $20 \%$ even if, in some cases, the companies had recognized significant goodwill in financial statement. Conversely, in 2011, 5 companies (out of 37) had a compliance score more than $80 \%$ and only one company had a bad level of compliance on goodwill disclosure (lower than $20 \%$ ).

Nevertheless, it is important to underline that even in 2011 no companies reached full level of compliance on goodwill's disclosure.

Table 9. Compliance range 2007-2011

\begin{tabular}{|c|c|c|c|}
\hline \multicolumn{4}{|c|}{2011} \\
\hline Range & $N$ & \% sample analyzed & Cumulative frequency \\
\hline $0-20 \%$ & 1 & $3 \%$ & $3 \%$ \\
\hline $21 \%-40 \%$ & 9 & $24 \%$ & $27 \%$ \\
\hline $41 \%-60 \%$ & 14 & $38 \%$ & $65 \%$ \\
\hline $61 \%-80 \%$ & 8 & $22 \%$ & $86 \%$ \\
\hline $81 \%-95 \%$ & 5 & $14 \%$ & $100 \%$ \\
\hline $95 \%-100 \%$ & 0 & $0 \%$ & $100 \%$ \\
\hline Total & 37 & $100 \%$ & \\
\hline \multicolumn{4}{|c|}{2010} \\
\hline Range & $N$ & \% sample analyzed & Cumulative frequency \\
\hline $0-20 \%$ & 1 & $3 \%$ & $3 \%$ \\
\hline $21 \%-40 \%$ & 14 & $38 \%$ & $41 \%$ \\
\hline
\end{tabular}




\begin{tabular}{|c|c|c|c|}
\hline $41 \%-60 \%$ & 11 & $30 \%$ & $70 \%$ \\
\hline $61 \%-80 \%$ & 7 & $19 \%$ & $89 \%$ \\
\hline $81 \%-95 \%$ & 4 & $11 \%$ & $100 \%$ \\
\hline $95 \%-100 \&$ & 0 & $0 \%$ & $100 \%$ \\
\hline Total & 37 & $100 \%$ & \\
\hline \multicolumn{4}{|c|}{2009} \\
\hline Range & $N$ & $\%$ sample analyzed & Cumulative frequency \\
\hline $0-20 \%$ & 0 & $0 \%$ & $0 \%$ \\
\hline $21 \%-40 \%$ & 17 & $47 \%$ & $47 \%$ \\
\hline $41 \%-60 \%$ & 12 & $33 \%$ & $81 \%$ \\
\hline $61 \%-80 \%$ & 4 & $11 \%$ & $92 \%$ \\
\hline $81 \%-95 \%$ & 3 & $8 \%$ & $100 \%$ \\
\hline $95 \%-100 \%$ & 0 & $0 \%$ & $100 \%$ \\
\hline Total & 36 & $100 \%$ & \\
\hline \multicolumn{4}{|c|}{2008} \\
\hline Range & $N$ & $\%$ sample analyzed & Cumulative frequency \\
\hline $0-20 \%$ & 1 & $3 \%$ & $3 \%$ \\
\hline $21 \%-40 \%$ & 16 & $46 \%$ & $49 \%$ \\
\hline $41 \%-60 \%$ & 11 & $31 \%$ & $80 \%$ \\
\hline $61 \%-80 \%$ & 5 & $14 \%$ & $94 \%$ \\
\hline $81 \%-95 \%$ & 2 & $6 \%$ & $100 \%$ \\
\hline $95 \%-100 \%$ & 0 & $0 \%$ & $100 \%$ \\
\hline Total & 35 & $100 \%$ & \\
\hline \multicolumn{4}{|c|}{2007} \\
\hline Range & $N$. & $\%$ sample analyzed & Cumulative frequency \\
\hline $0-20 \%$ & 16 & $50 \%$ & $50 \%$ \\
\hline $21 \%-40 \%$ & 10 & $31 \%$ & $81 \%$ \\
\hline $41 \%-60 \%$ & 4 & $13 \%$ & $94 \%$ \\
\hline $61 \%-80 \%$ & 2 & $6 \%$ & $100 \%$ \\
\hline $81 \%-95 \%$ & 0 & $0 \%$ & $100 \%$ \\
\hline $95 \%-100 \%$ & 0 & $0 \%$ & $100 \%$ \\
\hline Total & 32 & $100 \%$ & \\
\hline
\end{tabular}

Figure 1 highlights the trend of mode, mean and median values of disclosure on goodwill's compliance with the requirements of IAS 36 in the period 2007-2011.

The increasing trend of mean and median values confirms the improvement of disclosure's quality, as shown in the previous Table.

We can observe that in the first period there are companies that do not provide any information on economic evaluation aimed at testing the recoverable amount of goodwill in consolidated financial statements.

From this point of view, the decrease of mode value registered in 2011 (35.29\% in 2011; 50\% in 2010)-even if it is not an indicator of a decrease in the disclosure-highlights that, even in recent times, cases of not compliance still remain.

Table 10 displays that in 2008 for many companies it has been a turning point concerning compliance with 
requirements of IAS 36. In this period, in fact, the median and mean values have registered an important increase (respectively 23\% and 19\%).

This positive change is higher that the one the indicators have reached on the whole in the three years (2009-2011). It is important to notice that, at this regard, the number of companies that registered an impairment loss of goodwill in 2008 is significantly superior to the one in 2007 (see Table 5).

Table 10. IAS 36 Compliance. Disclosure score-mode, mean and median 2007-2011

\begin{tabular}{lccccc}
\hline & $\mathbf{2 0 0 7}$ & $\mathbf{2 0 0 8}$ & $\mathbf{2 0 0 9}$ & $\mathbf{2 0 1 0}$ & $\mathbf{2 0 1 1}$ \\
\hline Compliance IAS Disclosure score: Mean & $23 \%$ & $42 \%$ & $47 \%$ & $50 \%$ & $55 \%$ \\
Compliance IAS Disclosure score: Median & $20 \%$ & $43 \%$ & $44 \%$ & $50 \%$ & $53 \%$ \\
Compliance Disclosure score: Mode & $0 \%$ & $26 \%$ & $28 \%$ & $50 \%$ & $35 \%$ \\
\hline
\end{tabular}

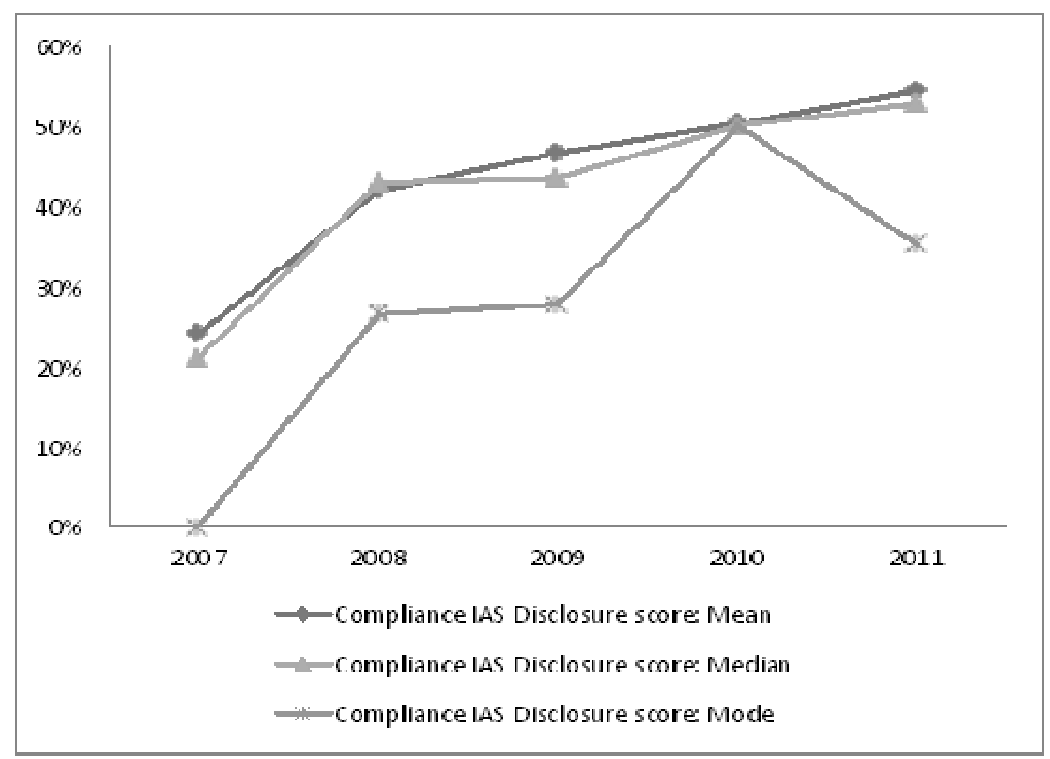

Figure 1. IAS 36 compliance. Disclosure score — mode, mean and median 2007-2011

\subsection{IAS/IFRS Disclosure- Evaluation for Subject}

Table 11. Compliance disclosure score for subject (ex IAS 36)

\begin{tabular}{|c|c|c|c|c|c|}
\hline & 2011 & 2010 & 2009 & 2008 & 2007 \\
\hline \multicolumn{6}{|l|}{ Basis of value } \\
\hline $\begin{array}{l}\text { Has the entity disclosed the basis on which the CGU's recoverable amount has determined } \\
\text { (fair value or value in use)? }\end{array}$ & $99 \%$ & $99 \%$ & $99 \%$ & $99 \%$ & $89 \%$ \\
\hline \multicolumn{6}{|c|}{ Value in use - Value in use - Disclosure on future cash flow for the period covered by the most recent budget/forecast } \\
\hline $\begin{array}{l}\text { Has the entity disclosed each key assumption of macro-economic source on which } \\
\text { management has based its cash flows projections for the period covered by the most } \\
\text { recent budgets/forecasts (IAS } 36 \text {, par. } 134 \text {, letter d) i). }\end{array}$ & $34 \%$ & $24 \%$ & $18 \%$ & $16 \%$ & $6 \%$ \\
\hline $\begin{array}{l}\text { Has the entity disclosed each key assumptions of internal source on which management } \\
\text { has based its cash flows projections for the period covered by the most recent } \\
\text { budget/forecast? (IAS } 36 \text {, par. 134, let. d) i). }\end{array}$ & $58 \%$ & $54 \%$ & $49 \%$ & $41 \%$ & $26 \%$ \\
\hline $\begin{array}{l}\text { Has the entity described the management's approach to determining the value(s) assigned } \\
\text { to each key assumption on which management has based its cash flows projections for the } \\
\text { period covered by the most recent budget/forecast? (IAS } 36 \text {, par. } 134 \text {, lett. d) ii) }\end{array}$ & $46 \%$ & $36 \%$ & $32 \%$ & $30 \%$ & $18 \%$ \\
\hline
\end{tabular}


Has the entity disclosed the period covered by the most recent budget/forecast?

Has the entity disclosed the reasons that justify the adoption of a period covered by the most recent budget/forecast exceeding five years? (only if this option is exercised)

$\begin{array}{lllll}88 \% & 89 \% & 88 \% & 91 \% & 61 \% \\ 60 \% & 64 \% & 45 \% & 44 \% & 20 \%\end{array}$

\section{Value in use-Terminal Value}

Has the entity disclosed the approach applied to assign value(s) to each key assumption concerning future cash flows for the period over which management has projected cash flows based on financial budget/forecast?

$47 \% \quad 39 \% \quad 38 \% \quad 27 \% \quad 8 \%$

Has the entity disclosed the approach to assign value(s) to each key assumption concerning discount rate used for the estimation of terminal value? (IAS 36, par. 134, let. d) ii)

\section{Value in use - Discount rate for the period covered by the most recent budget/forecast}

Has the entity disclosed the approach adopted to assign value(s) of each key assumptions concerning the discount rate? (IAS 36, par. 134, lett. d) ii)

Has the entity disclosed discount rate applied for the projections of cash flows?

\begin{tabular}{lllll}
$51 \%$ & $39 \%$ & $43 \%$ & $30 \%$ & $18 \%$ \\
$88 \%$ & $89 \%$ & $84 \%$ & $80 \%$ & $52 \%$ \\
\hline
\end{tabular}

\section{Value in use - Growth Rate}

Has the entity disclosed the growth rate $(\mathrm{g})$ used to extrapolate future cash flows for the period over which management has projected cash flows based on financial budget/forecast?

Has the entity specified whether growth rate $g$ is compliant with the long-term average growth rate for the products, industries, or country or countries in which the entity operates?

Has the entity explained the decision to adopt a growth rate exceeding the long-term average growth rate for the products, industries, or country or countries in which the entity operates? (only if this option is exercised)

$91 \% \quad 85 \% \quad 78 \% \quad 73 \% \quad 40 \%$

$35 \% \quad 35 \% \quad 29 \% \quad 29 \% \quad 23 \%$

Value in use-Coherence of key assumptions

Has the entity disclosed if values assigned to each key assumptions reflect past experience? (IAS 36, par. 134, let. d) ii)

$\begin{array}{lllll}36 \% & 36 \% & 30 \% & 17 \% & 2 \% \\ 33 \% & 20 \% & 22 \% & 20 \% & 13 \%\end{array}$

Has the entity disclosed if values assigned to each key assumptions differ from past experience or external source of information? (IAS 36, par. 134, let. d) ii)

\section{Fair value Disclosure}

Has the entity described the methodology used to determine fair value less costs to sell?

If fair values less costs to sell is not determined using an observable market price for the CGU, has the entity described each key assumption on which management has based its determination of fair value less costs to sell?

Has the entity described management's approach to determining the value (values) assigned to each key assumption?

$\begin{array}{lcccc}\text { No FV } & 100 \% & 100 \% & 50 \% & \text { No FV } \\ \text { No FV } & \text { N/A* } & \text { N/A } & \text { N/A } & \text { No FV } \\ \text { No FV } & \text { N/A } & \text { N/A } & \text { N/A } & \text { No FV } \\ \text { No FV } & \text { N/A } & \text { N/A } & \text { N/A } & \text { No FV } \\ \text { No FV } & \text { N/A } & \text { N/A } & \text { N/A } & \text { No FV } \\ & & & & \\ \text { No FV } & \text { N/A } & \text { N/A } & \text { N/A } & \text { No FV } \\ \text { No FV } & \text { N/A } & \text { N/A } & \text { N/A } & \text { No FV }\end{array}$

Has the entity disclosed if values of each key assumption reflect past experience or, if appropriate, are consistent with external sources of information?

flow projections?

\section{Sensitivity Analysis}

Has the entity disclosed the amount by which the CGU's recoverable amount exceeds its carrying amount?

\begin{tabular}{rrrrr}
$35 \%$ & $29 \%$ & $14 \%$ & $6 \%$ & $0 \%$ \\
$51 \%$ & $49 \%$ & $43 \%$ & $34 \%$ & $17 \%$ \\
\hline
\end{tabular}

Has the entity disclosed the value assigned to the key assumption?

$51 \%$


Has the entity disclosed the amount by which the value assigned to the key assumption must change, after incorporating any consequential effects of the change on the other variables used to measure recoverable amount, in order for the CGU's recoverable $48 \% \quad 43 \% \quad 33 \% \quad 24 \%$ $2 \%$ amount to be equal to its carrying amount?

$* \mathrm{~N} / \mathrm{A}=$ For the entity that applies fair values less cost to sell, the recoverable amount of CGU is determined on the basis of observable market prices.

Table 11, confirming the higher accuracy in the application of requirements on goodwill's disclosure, highlights an increase of quality of disclosure for all the requirements of IAS 36 in the period covered by the analysis.

In period 2011 the higher level of compliance concern the following areas of disclosure:

- declaration on basis of value that has been applied (99\%),

- information on the period covered by the most recent budget/forecast $(88 \%)$,

- information on growth rate $(91 \%)$ and discount rate $(88 \%)$.

As far as disclosure on basis of value, we observe that compliance level of disclosure was large also in 2007 $(89 \%)$. Conversely, for the other area of disclosure we register a remarkable increase of compliance, especially in 2008.

With regards to disclosure on growth rate, even if companies, nearly every case, disclose the value of this parameter, we observe that there is a significant lack of information about the adoption to apply a growth rate exceeding the long-term average growth rate for the products, industries, or country or countries in which the entity operates.

Considering the other area of disclosure on IAS 36, the financial statements register significant lack of information on key assumptions used to estimate future cash flows (in particular for external source of information) and for the methodologies applied to assign a value to these key assumptions.

On this aspect, it is interesting to notice that this lack regards also discount rate. In other words, almost all the companies in the sample disclose the amount of discount rate but usually they do not provide information on the criteria used to assign a value to this key assumption, limiting to declare only the adoption of CAPM.

In relation to terminal value's disclosure, we register partially positive results. Starting from 2008, some companies in the sample start to provide with adequate information on future cash flows and on discount rate pertaining terminal value.

In particular in the financial statements we have analyzed it is specified:

- if the future cash flow coincides with the one of the last year of the most recent budget/forecast or, alternatively, if it is used a normalized flow;

- if the discount rate is the same of the one applied for the most recent budget/forecast.

We have obtained similar conclusion by referring to the amount of information on sensitivity analysis.

It is useful to observe that, following the above mentioned recommendations of Authorities, starting from 2009, it is most frequently that companies disclose on the results of sensitivity analysis even if the company has impaired goodwill (IAS 36 does not require disclosure about this in case of impairment).

However we highlights that the maximum score reached by a company in the sample does not exceed $51 \%$.

As far as disclosure on fair value, we observe that the small number of companies that apply this basis of value disclose the information required by IAS 36. The information on key assumption is not provided by the companies as this information is not required by IAS 36 if it is not applied the income approach.

\subsection{Italian Standard Setter (OIC) and Italian Authority Disclosure}

Figure 2 and Table 12 show, as we have noticed for mandatory disclosure of IAS 36, a significant increase of disclosure's quality required by National Boards. Even if, looking at the data, it is clear that the growth occurs less that the one registered for mandatory disclosure.

Table 13 highlights that companies have not adopted the recommendations of Authorities that have suggested to disclose on the components of discount rate. The most significant omissions regard (level of compliance is about at $2 \%$ ): 
- the information on the cost of debt and on mix of financial capital/debt $(\mathrm{D} / \mathrm{E}+\mathrm{D} ; \mathrm{E} / \mathrm{E}+\mathrm{D})$ used to determine WACC. This disclosure is not required if the entity has applied an equity approach for the evaluation of CGU;

- $\quad$ some specific information on impairment's indicators of external source of information, if the entity has not impaired.

Table 14 exhibits the score reached by banks and insurance companies in relation to the disclosure recommended by OIC, effective starting from 2010. Even in this case, the results do not appear satisfactory, even if the compliance level is higher than the one we can observe in Table 13.

Table 12. Compliance Authority/OIC Disclosure score - Mode, Mean and Median 2007-2011

\begin{tabular}{lccc}
\hline & $\mathbf{2 0 0 9}$ & $\mathbf{2 0 1 0}$ & $\mathbf{2 0 1 1}$ \\
\hline Compliance Authority/OIC Disclosure score: Mean & $22 \%$ & $24 \%$ & $27 \%$ \\
Compliance Authority/OIC Disclosure score: Median & $13 \%$ & $14 \%$ & $13 \%$ \\
Compliance Authority/OIC Disclosure score: Mode & $\mathbf{0 \%}$ & $\mathbf{1 3 \%}$ & $\mathbf{1 3 \%}$ \\
\hline
\end{tabular}

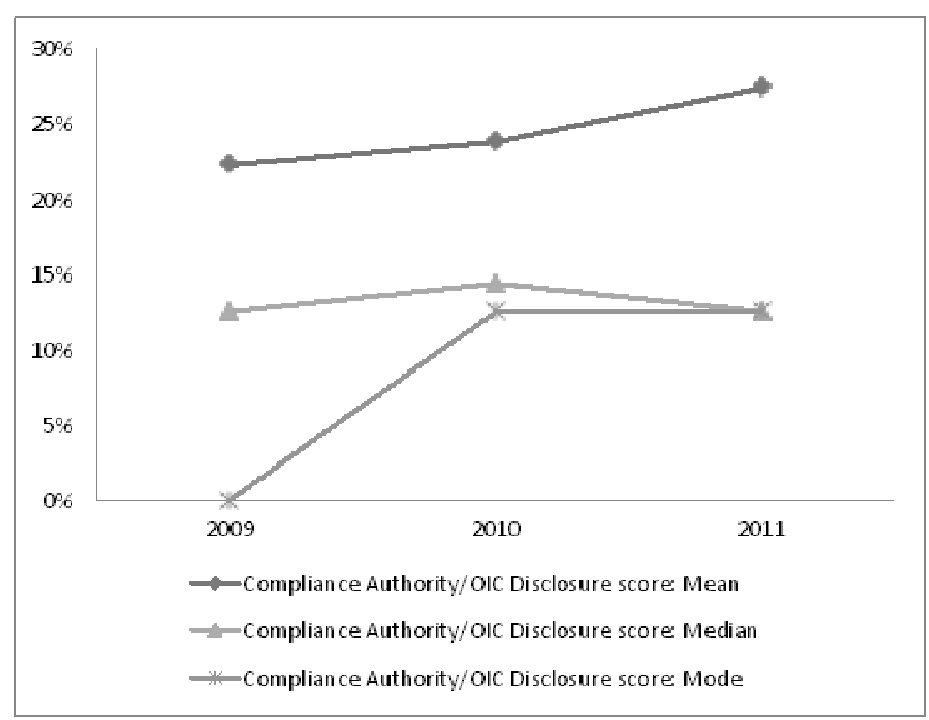

Figure 2. Compliance Authority/OIC disclosure score-mode, mean and median 2009-2011

Table 13. Compliance disclosure for subject (according to Authorities and OIC)

\begin{tabular}{|c|c|c|c|}
\hline Area of Disclosure & 2009 & 2010 & 2011 \\
\hline \multicolumn{4}{|l|}{ Discount rate disclosure } \\
\hline Is Risk-free-rate disclosed? & $22 \%$ & $21 \%$ & $26 \%$ \\
\hline Is Beta disclosed? & $26 \%$ & $25 \%$ & $28 \%$ \\
\hline Is Risk Premium disclosed? & $22 \%$ & $21 \%$ & $28 \%$ \\
\hline Is Cost of Debt disclosed? & $7 \%$ & $7 \%$ & $7 \%$ \\
\hline $\begin{array}{l}\text { Has the entity disclosed proportion of equity and debt on funding mix- if entity applies unlevered } \\
\text { cash flow? }\end{array}$ & $7 \%$ & $7 \%$ & $7 \%$ \\
\hline Has the entity specified if the discount rate corresponds to the one used in the previous period? & $15 \%$ & $25 \%$ & $30 \%$ \\
\hline Has the entity clarified if the discount rate is after or before taxes? & $46 \%$ & $57 \%$ & $64 \%$ \\
\hline \multicolumn{4}{|l|}{ Disclosure on external indicators of Impairment. Only if entity has not impaired goodwill } \\
\hline Has entity disclosed on presumed indicators of external sources of information in a complete way? & $7 \%$ & $6 \%$ & $2 \%$ \\
\hline
\end{tabular}


Table 14. Bank and insurance company: compliance OIC disclosure score for subject

\begin{tabular}{lcc}
\hline Compliance Analysis & $\mathbf{2 0 1 0}$ & $\mathbf{2 0 1 1}$ \\
\hline $\begin{array}{l}\text { Has entity disclosed the approach that has been applied for the budget/forecast ? (budget that has been } \\
\text { approved and publicized to the market; budget that has been approved and publicized to the market but not } \\
\text { more up-to-date) }\end{array}$ & $65 \%$ & $75 \%$ \\
\hline $\begin{array}{l}\text { Have the sensitivity analysis been made on the basis of following factors: future cash flow, growth rate, } \\
\text { discount rate? }\end{array}$ & $48 \%$ & $50 \%$ \\
Has the entity carried out also a variability analysis? & $10 \%$ & $10 \%$ \\
\hline
\end{tabular}

\subsection{Correlations}

The following charts exhibit the relation between the level of disclosure in 2011 by the companies in the sample and the following variables:

- Impairment rate (Figure 3)

- Goodwill/Equity (Figure 4)

- Market Capitalization (Figure 5)

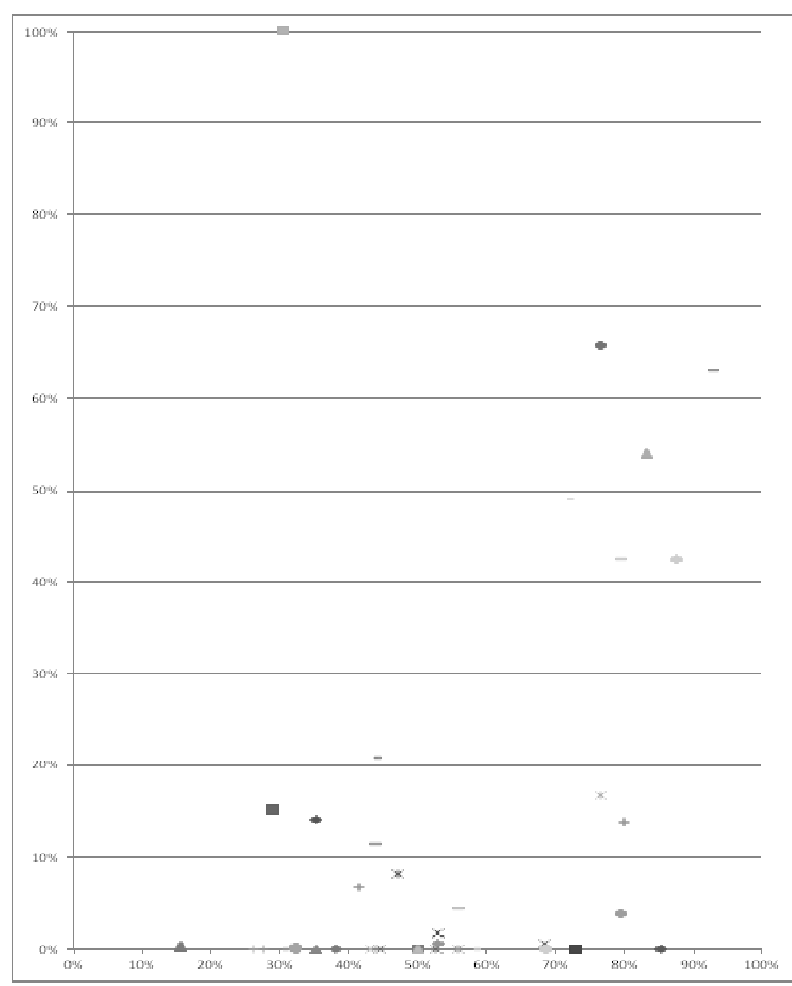

Figure 3. Scatter pattern impairment rate and level of disclosure

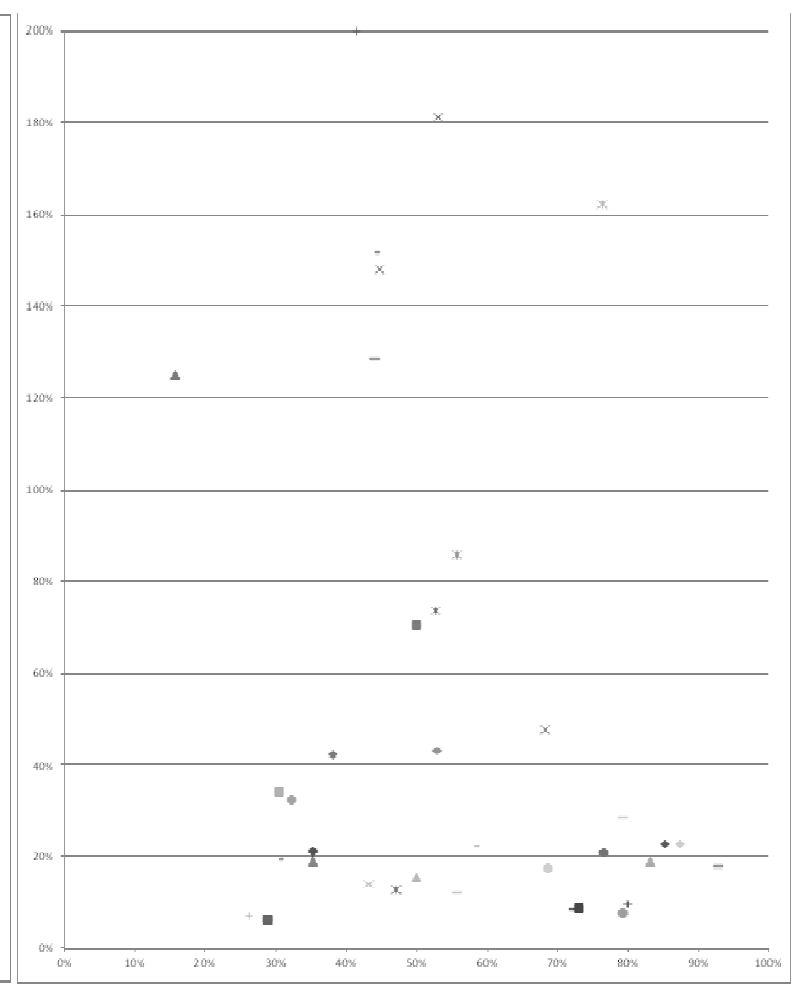

Figure 4. Scatter pattern goodwill/equity and level of disclosure

The results we have obtained exhibit that there is not a relation between the quality of mandatory disclosure on goodwill and the above-mentioned parameters.

Taking into account this consideration, we can highlight that:

- for many entities that have an high $\mathrm{G} / \mathrm{E}$, the level of compliance is lower to the one reached by entities that have lower level of $\mathrm{G} / \mathrm{E}$. We have reached similar results as far as market capitalization (even if the relation between the two parameters is lower);

- the entities that have recognized significant impairment losses (except for the case of a company that has a G/E not reliable because of the impairment loss regards a business combination occurred in the same period) reach a level of disclosure higher than $70 \%$. However, we can't state that there is a relation between quality of disclosure 
and goodwill's impairment because same results of disclosure are registered for the companies that have not impaired goodwill. Specifically 7 companies out of 13 companies, that in 2011 have a level of compliance higher than $70 \%$, have a I/G lower than $20 \%$.

In order to validate the absence of relation between impairment rate and amount of information in the notes, in Table 13 we exhibit the trend of disclosure compliance's level according to IAS 36 for the five companies that at 31st December 2011 registered the higher and the lower impairment rate.

Considering that, even if there is a significant increase of impairment rate, the number of companies that have not impaired $(\mathrm{I} / \mathrm{G}=0 \%)$ is material, we have selected the companies with the highest level of compliance (see Table 15 and Table 16).

For the both categories of companies, it can be observed an overall increase of disclosure that it is not related to the recognition of impairment loss. In few cases we note that the relevant increase of compliance occurs in the same period of impairment loss particularly high.

Another aspect we highlight is that the different approaches adopted by companies to be in line with the requirements of IAS 36: in some circumstances the growth of level of compliance occurs steadily; for other entities the improvement occurs in a period that does not correspond to the one of impairment loss recognition.

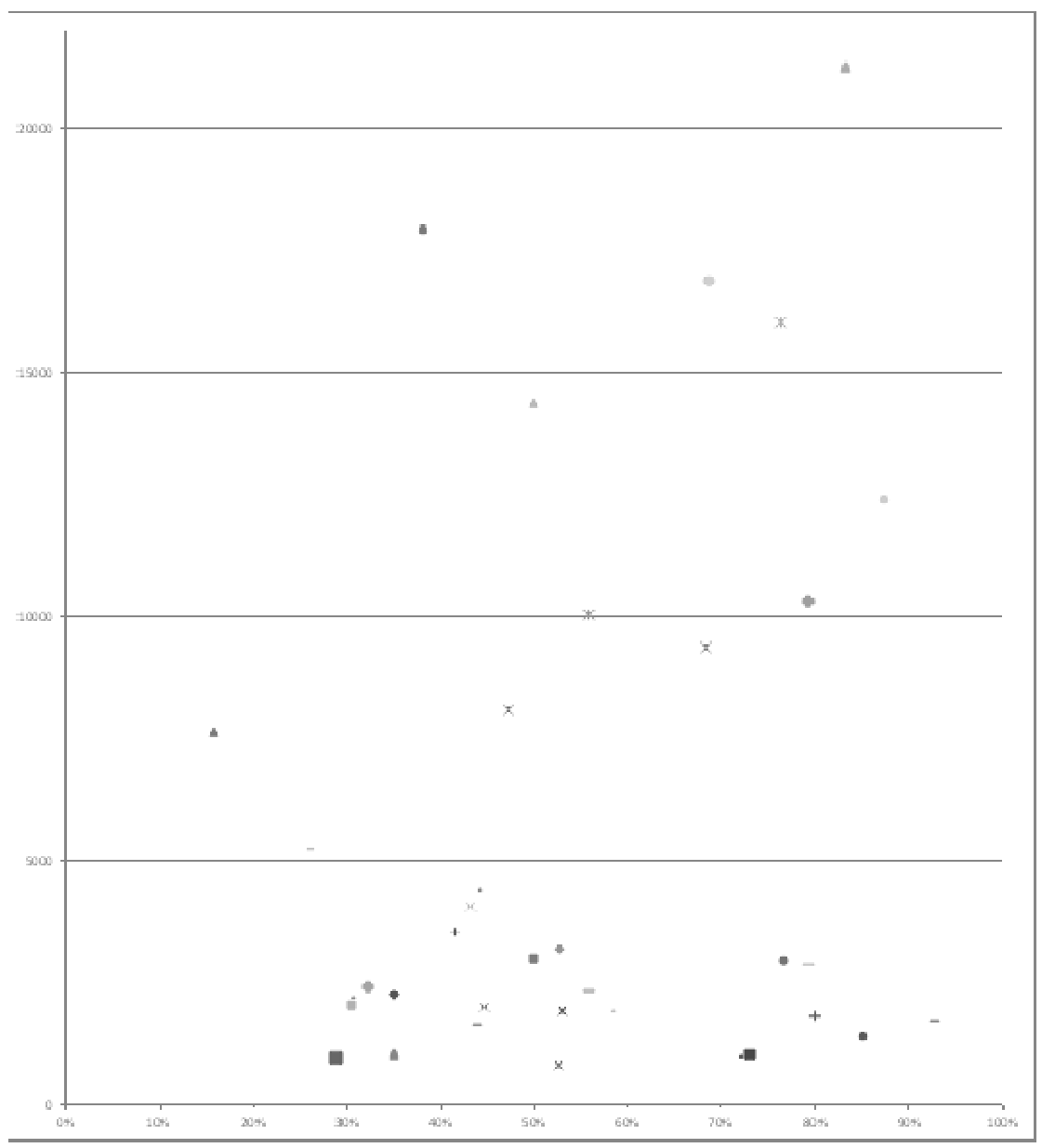

Figure 5. Scatter pattern market capitalization and level of disclosure 
Table 15. Compliance 2007-2011 for impairing entities

\begin{tabular}{|c|c|c|c|c|c|c|c|c|c|c|}
\hline \multirow{2}{*}{$\begin{array}{l}\text { Impairing } \\
\text { entities } 2011\end{array}$} & \multicolumn{2}{|c|}{2007} & \multicolumn{2}{|c|}{2008} & \multicolumn{2}{|c|}{2009} & \multicolumn{2}{|c|}{2010} & \multicolumn{2}{|c|}{2011} \\
\hline & $\mathbf{I} / \mathbf{G}$ & \% comp. & $\mathbf{I} / \mathbf{G}$ & $\%$ comp. & $\mathbf{I} / \mathbf{G}$ & $\%$ comp. & $\mathbf{I} / \mathbf{G}$ & \% comp. & $\mathbf{I} / \mathbf{G}$ & $\%$ comp. \\
\hline Entity 1 & $0 \%$ & $14 \%$ & $16 \%$ & $63 \%$ & $0 \%$ & $64 \%$ & $0 \%$ & $74 \%$ & $66 \%$ & $79 \%$ \\
\hline Entity 2 & $0 \%$ & $0 \%$ & $0 \%$ & $86 \%$ & $0 \%$ & $86 \%$ & $0 \%$ & $86 \%$ & $63 \%$ & $94 \%$ \\
\hline Entity 3 & $7 \%$ & $0 \%$ & $6 \%$ & $84 \%$ & $0 \%$ & $84 \%$ & $1 \%$ & $84 \%$ & $54 \%$ & $85 \%$ \\
\hline Entity 4 & $0 \%$ & $37 \%$ & $2 \%$ & $57 \%$ & $0 \%$ & $55 \%$ & $0 \%$ & $50 \%$ & $49 \%$ & $75 \%$ \\
\hline Entity 5 & $0 \%$ & $10 \%$ & $4 \%$ & $50 \%$ & $0 \%$ & $84 \%$ & $2 \%$ & $84 \%$ & $42 \%$ & $89 \%$ \\
\hline
\end{tabular}

Table 16. Compliance 2007-2011 for not impairing entities

\begin{tabular}{|c|c|c|c|c|c|c|c|c|c|c|}
\hline \multirow{2}{*}{$\begin{array}{l}\text { Not Impairing } \\
\text { entities } 2011\end{array}$} & \multicolumn{2}{|c|}{2007} & \multicolumn{2}{|c|}{2008} & \multicolumn{2}{|c|}{2009} & \multicolumn{2}{|c|}{2010} & \multicolumn{2}{|c|}{2011} \\
\hline & $\mathbf{I} / \mathbf{G}$ & $\%$ comp. & $\mathbf{I} / \mathbf{G}$ & $\%$ comp. & $\mathbf{I} / \mathbf{G}$ & $\%$ comp. & $\mathbf{I} / \mathbf{G}$ & $\%$ comp. & $\mathbf{I} / \mathbf{G}$ & $\%$ comp. \\
\hline Entity 1 & $0 \%$ & $58 \%$ & $33 \%$ & $58 \%$ & $2 \%$ & $79 \%$ & $1 \%$ & $79 \%$ & $0 \%$ & $87 \%$ \\
\hline Entity 2 & $0 \%$ & $32 \%$ & $0 \%$ & $32 \%$ & $0 \%$ & $37 \%$ & $0 \%$ & $77 \%$ & $0 \%$ & $77 \%$ \\
\hline Entity 3 & $0 \%$ & $26 \%$ & $16 \%$ & $33 \%$ & $0 \%$ & $39 \%$ & $0 \%$ & $72 \%$ & $0 \%$ & $72 \%$ \\
\hline Entity 4 & $0 \%$ & $5 \%$ & $0 \%$ & $50 \%$ & $0 \%$ & $63 \%$ & $0 \%$ & $63 \%$ & $0 \%$ & $63 \%$ \\
\hline Entity 5 & $0 \%$ & $11 \%$ & $0 \%$ & $50 \%$ & $0 \%$ & $61 \%$ & $1 \%$ & $61 \%$ & $0 \%$ & $61 \%$ \\
\hline
\end{tabular}

\section{Discussion and Conclusions}

From the analysis of financial statements of listed companies included in the sample and for the years 2007-2011, it is evident that the quality of disclosure on the impairment test of goodwill-evaluated in terms of compliance with the requirements of IAS 36 and with the guidelines recommended by the Authority and the national standard-setter - actually it is still very incomplete. At the same time, even if it is never achieved full compliance, the positive evolution of the mean score of level of disclosure from 2007 to 2011 shows, as expected, a greater sensitivity of companies that are willing to render easier the process of investors assessing the reliability of estimates made for the purpose of impairment testing.

Moreover, scores next to full compliance (above 90\%) can't be considered satisfactory because these are anyway expression of a breach of requirements ex IAS 36, even if these scores are not "pathological" as some ones analyzed in this study (for some companies the level of compliance is below $30 \%$ ).

From this point of view, the results of this study confirm some authoritative studies on this subject relating to a period prior to the one analyzed in this paper.

In contrast, as far as the period of the analysis (2007-2011) is concerned, the thesis according to which the level of disclosure depends on the decision of top management to impair or not to impair goodwill doesn't seem to be confirmed since the same level of disclosure is reached by firms with impairment rate profoundly different. Further analysis concerning the accounting behavior of a sub-sample of companies in the period 2007-2011 show that, frequently, the improvement of disclosure is not affected by the amount of impairment loss goodwill.

We have attempted to identify the reasons that, in the last years of analyzed period, have led companies to provide more detailed information regarding goodwill's impairment testing, it is reasonable to argue that the emergence of the first effects of the financial crisis (2008) and the recommendations of public Authorities have had a decisive role in this direction (2009).

As indicated in the previous paragraphs, many companies have registered a substantial increase in the quality of their disclosure in one of these periods and then they have registered a further enhancement in the following two years.

However, the widespread reluctance to provide information concerning the basic assumptions of the assessment leads to the conclusion that, in many cases, the application of Authorities' recommendations is mainly formal rather than substantive. In other words, the greater information in the notes may not be considered complete because often there is a lack of an adequate reporting on information sources. 
Therefore, the quality of disclosure does not seem to be an element in order to evaluate the correctness of the impairment tests' procedures carried out by the companies.

In such a context, it is necessary to wonder about the reasons justifying the "accounting attitude" of the companies in the sample.

The first reason may be sought in the excessive discretion or in poor comprehensibility of the disclosure requirements contained in the paragraph 134 of IAS 36. By examining these rules, we observe that for some of them, there is no doubt of interpretation: it is the case for the requirements concerning the obligation to disclose:

(a) the basis of value that has been used;

(b) the value assigned to discount rate and the growth rate;

(c) the period covered by the most recent budget/forecast for the cash flow projections;

(d) if the values assigned to the key assumptions are consistent with past experience or with external sources of information.

Conversely, the declaration of the basic assumptions of the evaluation and the presentation of the sensitivity analysis' results requires the exercise of professional judgment to assess both the sensitivity of the recoverable amount to the key assumptions that have been adopted and the possibility of an adverse change in a key assumption to some extent to require a goodwill's impairment in the future.

Such reasons do not seem to justify completely the results of the research because there is a significant lack of disclosure compliance even for clear and comprehensible disclosure requirements.

In 2011 , only $33 \%$ of the companies in the sample declare if the values assigned to the key assumptions are consistent with past experience or with external sources of information and only $60 \%$ of companies adopting plans for a period exceeding five years illustrate the reasons that justify this option.

In addition, especially in the early years of the period covered by the analysis, there are examples of companies that did not communicate the discount rate and/or the rate of growth.

Another reason could be the difficulty to fulfill the disclosure obligations set forth in IAS 36. This explanation, however, is not sustainable because the information required by IASB is necessary for the procedure of impairment. Therefore, these information can be extrapolated from evaluation's report drawn up by the expert (internal or external to the entity) who made the estimates, if these reports have been prepared in compliance with generally accepted evaluation principles (IVS 2011).

In our opinion, it may seem reasonable to argue that the partial compliance with requirements of IAS 36 may be justified by the fact that the potential benefits of a full compliance for the companies are lower than the costs occurring if companies disclose and publish sensitive information to the market about its expected cash flow and income.

Regarding the limitations of the research, we highlight that the analysis has been conducted on a small number of companies and, therefore, the results could change if the study was extended to other listed companies belonging to segments identified by the Italian Stock Exchange. Secondly, for the evaluation of the information provided by the companies - in particular to those related to the key assumptions - the assigned score may be affected by a certain degree of subjectivity of authors.

Since IFRS are mandatory for all European listed companies and have been adopted in several countries, our results could be of interest also outside the Italian scenario and this study can improve the analysis of the effective implementation and disclosure required.

As far as the possible future developments of the research, it might be useful to verify, through regression models, if the increase of the disclosure registered for a company in a certain year produces benefits regarding:

- an increase of profitability in the following period;

- a decrease of cost of capital in the following period;

- an increase of market capitalization for the following period.

Such a study could confirm the intuition of some researchers that believe that the transparency of the information, in certain contexts, is a premium factor higher than the final result of the impairment test, provided that the three variables just mentioned are influenced by a plurality of other factors, internal and external to the company, different from the level of disclosure's compliance.

\section{References}


Armitage, S., \& Marston, C. (2008). Corporate disclosure, cost of capital and reputation: Evidence from finance directors. The British Accounting Review, 40(4). 314-336. http://dx.doi.org/10.1016/j.bar.2008.06.003

Banca d'Italia, ISVAP, \& CONSOB. (2009). Informazioni da fornire nelle relazioni finanziarie sulla continuità aziendale, sui rischi finanziari, sulle verifiche per riduzione di valore delle attività e sulle incertezze sull'utilizzo delle stime. Retrieved from www.consob.it

Banca d'Italia, ISVAP, \& CONSOB. (2010). Esercizi 2009 e 2010. Informazioni da fornire nelle relazioni finanziarie sulle verifiche per riduzione di valore delle attività (impairment test) sulle clausole contrattuali dei debiti finanziari, sulle ristrutturazioni di debiti e sulla gerarchia del fair value. Retrieved from www.consob.it

Barth, M., Landsman, W., \& Lang, M. (2008). International accounting standards and accounting quality. Journal of Accounting Research, 46, 467-728. http://dx.doi.org/10.1111/j.1475-679X.2008.00287.x

Bergamini, I., \& Zambon, S. (2002). A scoring methodology for ranking company disclosure on intangibles. $E U$ PRISM Research Project, WP, 4.

Biancone, P. P. (2012). IFRS: Italian Experience on Impairment Test of Goodwill. International Journal of Advances in Management Science, 1(3).

Bloom, M. (2009). Accounting for Goodwill. Abacus, 45(3). 379-389. http://dx.doi.org/10.1111/j.1467-6281.2009.00295.x

Botosan, C. (1997). Disclosure Level and the Cost of Equity Capital. The Accounting Review, 72(3), 323-349. http://dx.doi.org/10.1111/1475-679X.00037

Botosan, C. (2006). Disclosure and the cost of capital: what do we know? Accounting and Business Research, 31-40. http://dx.doi.org/10.1080/00014788.2006.9730042

Botosan, C. A., \& Plumlee, M. A. (2002). A Re-examination of Disclosure and the Expected Cost of Equity Capital. Journal of Accounting Research, 40(1). http://dx.doi.org/10.1111/1475-679X.00037

Carlin, T., \& Finch, N. (2010). Evidence on IFRS goodwill impairment testing by Australian and New Zealand firms. Managerial Finance, 36(9), 785-798. http://dx.doi.org/10.1108/03074351011064654

Camodeca, R., \& Almici, A. (2012). The information content of goodwill impairment before and after the Financial Crisis: evidence from European listed banks. 7th Annual Business Research Conference, World Business Institute, Australia. Retrieved from http://www.wbiconpro.com

Carlin, T. M., \& Finch, N. (2009). Discount Rates in Disarray: Evidence on Flawed Goodwill Impairment Testing. Australian Accounting Review, 19(51), 326-336. http://dx.doi.org/10.1111/j.1835-2561.2009.00069.x

Chalmers, K. G., Godfrey, J. M., \& Webster, J. C. (2011). Does a goodwill impairment regime better reflect the underlying economic attributes of goodwill? Accounting \& Finance, 51, 634-660. http://dx.doi.org/10.1111/j.1467-629X.2010.00364.x

Colquitt, L., \& Wilson, A. (2002). The elimination of pooling-of-interests and goodwill amortization and its effect on the insurance industry. Journal of Insurance Regulation, 20(3), 338-351.

D’Alauro, G. (2011). L'avviamento nei bilanci aziendali: Impairment test and disclosure. Financial Reporting, 3, $11-43$.

Daske, H., \& Gebhardt, G. (2006). International Financial Reporting Standards and Experts' Perceptions of Disclosure Quality. Abacus, 42, 461-498. http://dx.doi.org/10.1111/j.1467-6281.2006.00211.x

Daske, H., Hail, L., Leuz, C., \& Verdi, R. (2013). Adopting a Label: Heterogeneity in the Economic Consequences Around IAS/IFRS Adoptions. Journal of Accounting Research, 51(3), 495-547, http://dx.doi.org/10.1111/1475-679X.12005

Devalle, A., \& Rizzato, F. (2012). The quality of mandatory disclosure: the impairment of goodwill. An empirical analysis of European listed companies. Procedia Economics and Finance, (2), 101-108. http://dx.doi.org/10.1016/S2212-5671(12)00069-X

Donnelly, T., \& Keys, R. (2002). Business Combinations and Intangible Assets. Australian CPA, 72(4), 68-69.

Douglas, W. D., \& Verrecchia, R. E. (1991). Disclosure, liquidity and cost of capital. Journal of Finance, 46(4), 1325-1359. http://dx.doi.org/10.1111/j.1540-6261.1991.tb04620.x 
ESMA. (2013). European enforcers review of impairment of goodwill and other intangible assets in the IFRS financial statements. Retrieved from http://www.esma.europa.eu

Gu, F., \& Lev, B. (2011). Overpriced Shares, Ill-Advised Acquisitions, and Goodwill Impairment. The Accounting Review, 86(6), 1995-2022. http://dx.doi.org/10.2308/accr-10131

Guatri, L. (2009). Rischio IAS/IFRS in periodi di crisi endemica. La Valutazione delle Aziende, 52, 3-8.

Guatri, L., \& Bini, M. (2009). L'impairment Test nell'attuale crisi finanziaria e dei mercati reali. Milano: Egea.

Hartwig, F. (2012). Swedish and Dutch listed companies' compliance with IAS 36 paragraph 134, working paper.

IFRS Foundations. (2013a). International Financial Reporting Standards IFRS (Red Book). Retrieved from http://www.iasb.org

IFRS Foundations. (2013b). IASB and IFRS Interpretations Committee Due Process Handbook. Retrieved from http://www.iasb.org

International Accounting Standard Board. (2004a). IAS 36-Impairment of assets. Retrieved from http://www.iasb.org

International Accounting Standard Board. (2004b). IFRS 3-Business Combinations. Retrieved from http://www.iasb.org

International Accounting Standard Board. (2010). The Conceptual Framework for Financial Reporting. Retrieved from http://www.iasb.org

International Accounting Standard Board. (2013). Exposure Draft Recoverable Amount Disclosures for NonFinancial Assets. Retrieved from http://www.iasb.org

International Valuation Standard Board. (2011). International Valuation Standard 2011. Retrieved from http://www.ivsc.org

Liberatore, G., \& Mazzi, F. (2011). Informativa Tasso di attualizzazione nella stima dell'avviamento secondo lo IAS 36: un confronto fra Italia e Paesinordici. Financial Reporting, 4, 107-133.

Liberatore, G., Ridi, T., \& Di Pietro, F. (2012). Rilevanza E Affidabilità del valore contabile di'avviamento e dei beni immateriali sul mercato italiano. Financial Reporting, 3, 31-50.

Massari, M., \& Zanetti, L. (2004). Valutazione Finanziaria. Milano: McGraw-Hill.

Massoud, M. F., \& Raiborn, C. A. (2003). Accounting for Goodwill: Are we better off? Review of Business, 24(2), 26-32.

Organismo Italiano di Contabilità. (2009). Applicazione 2-“Impairment e avviamento". Retrieved from http://www.fondazioneoic.eu

Organismo Italiano di Contabilità. (2011a). Applicazione 2.1-“Impairment e avviamento" per ilsettorebancario. Retrieved from http://www.fondazioneoic.eu

Organismo Italiano di Contabilità. (2011b). Applicazione 2.2- "Impairment e avviamento" per il settore assicurativo. Retrieved from http://www.fondazioneoic.eu

Organismo Italiano di Valutazione. (2012). Discussion Paper Impairment test dell'avviamento in contesti di crisifinanziaria e reale: lineeguida. Retrieved from www.fondazioneoiv.it

Petersen, C., \& Plenborg, T. (2010). How Do Firms Implement Impairment Tests of Goodwill? Abacus, 46(4), 419-446. http://dx.doi.org/10.1111/j.1467-6281.2010.00326.x

Quagli, A. (2011). Goodwill accounting as a missing link between financial and management accounting: literature review and research agenda. Financial reporting, 3, 17-39.

Teodori, C., \& Veneziani, M. (2010). Intangible assets in annual reports: a disclosure index. Department of Business Studies, University of Brescia.

Verriest, A., \& Gaeremynck, A. (2009). What determines goodwill impairment? Review of Business and Economics, 54(2), 1-23.

Watts, R. L. (2003). Conservatism in Accounting. Part q: Explanations and Implications. Accounting Horizons: 17(3), 207-221. http://dx.doi.org/10.2308/acch.2003.17.4.287

Wines, G., Dagwell, R., \& Windsor, C. (2007). Implications of the IFRS goodwill accounting treatment. 
Managerial Auditing Journal, 22(9), 862-880. http://dx.doi.org/10.1108/02686900710829381

\section{Copyrights}

Copyright for this article is retained by the author(s), with first publication rights granted to the journal.

This is an open-access article distributed under the terms and conditions of the Creative Commons Attribution license (http://creativecommons.org/licenses/by/3.0/). 